\title{
VI. COMMENTS ON OPAL PHYTOLITHS AND STRATIGRAPHY OF NEOGENE SILICOFLAGELLATES AND COCCOLITHS AT DEEP SEA DRILLING PROJECT SITE 397 OFF NORTHWEST AFRICA
}

\author{
David Bukry, U.S. Geological Survey, La Jolla, California
}

\section{INTRODUCTION}

This chapter presents observations on the occurrence of opal phytoliths, silicoflagellates, and coccoliths at Site 397 of Deep Sea Drilling Project Leg 47A. Leg 47A began in March 1976 at the Canary Islands and ended at Vigo, Spain, in April 1976. Drilling yielded 156 cores at Site 397 on the continental slope off Cape Bojador (Figure 1). Light-microscope techniques were used to study the Neogene silicoflagellates, coccoliths, and opal phytoliths in 80 samples from Cores 1 to 98 ( 0 to $940 \mathrm{~m}$ ) of Hole 397 and Cores 1 to 32 (707 to $1287 \mathrm{~m}$ ) of Hole 397A. Biostratigraphic zonation for coccoliths follows Bukry (1973, 1975a); silicoflagellate zonation is explained in text. Silicoflagellate assemblages at Site 397 are late Pliocene and Quaternary. The species array is similar to that of the Walvis Ridge to the south (Site 362) and the Mid-Atlantic Ridge to the north (Site 333). Three new taxa of silicoflagellates are described: Dictyocha bojadorina n. sp., D. calida ampliata $\mathrm{n}$. subsp., and $D$. perlaevis flexatella $\mathrm{n}$. subsp. Two new combinations are proposed and discussed: Dictyocha constricta (Schulz) n. comb. and D. longispina (Lemmerman) n. comb.

Opal phytoliths, which are silicified casts of epidermal cells from terrestrial plants, mainly grasses, occur in low or moderate abundance at some levels in the Pliocene and Quaternary of Cores 2 to 21 . They are absent from the Miocene samples examined. The opal phytoliths are associated with fresh-water diatoms such as Melosira granulata. Together they suggest deposits that were enriched by airborne particles during arid times on the nearby continent (Kolbe, 1957; Folger et al., 1967).

\section{COCCOLITHS}

Coccoliths are abundant in nearly all samples studied from Cores 2 to 21 and Cores 52 to 98 of Hole 397 and Cores 4 to 32 of Hole 397A (Figure 2). Pliocene and Quaternary samples of Cores 2 to 21 of Hole 397 contain well-preserved coccoliths; reworked Cretaceous and Miocene species occur in several samples. The assemblages are also characterized by Coccolithus pelagicus, a prominent late Quaternary temperate species ( $9^{\circ} \mathrm{C}$ optimum; McIntyre et al., 1972). The specimens are large and abundant, suggesting that the species had its optimum ecologic conditions (Hecht, 1976a,b) at Site 397 during Pliocene and Quaternary. Contrarily, no specimens of Ceratolithus and only a trace of Scyphosphaera were found in the samples. Both taxa seem

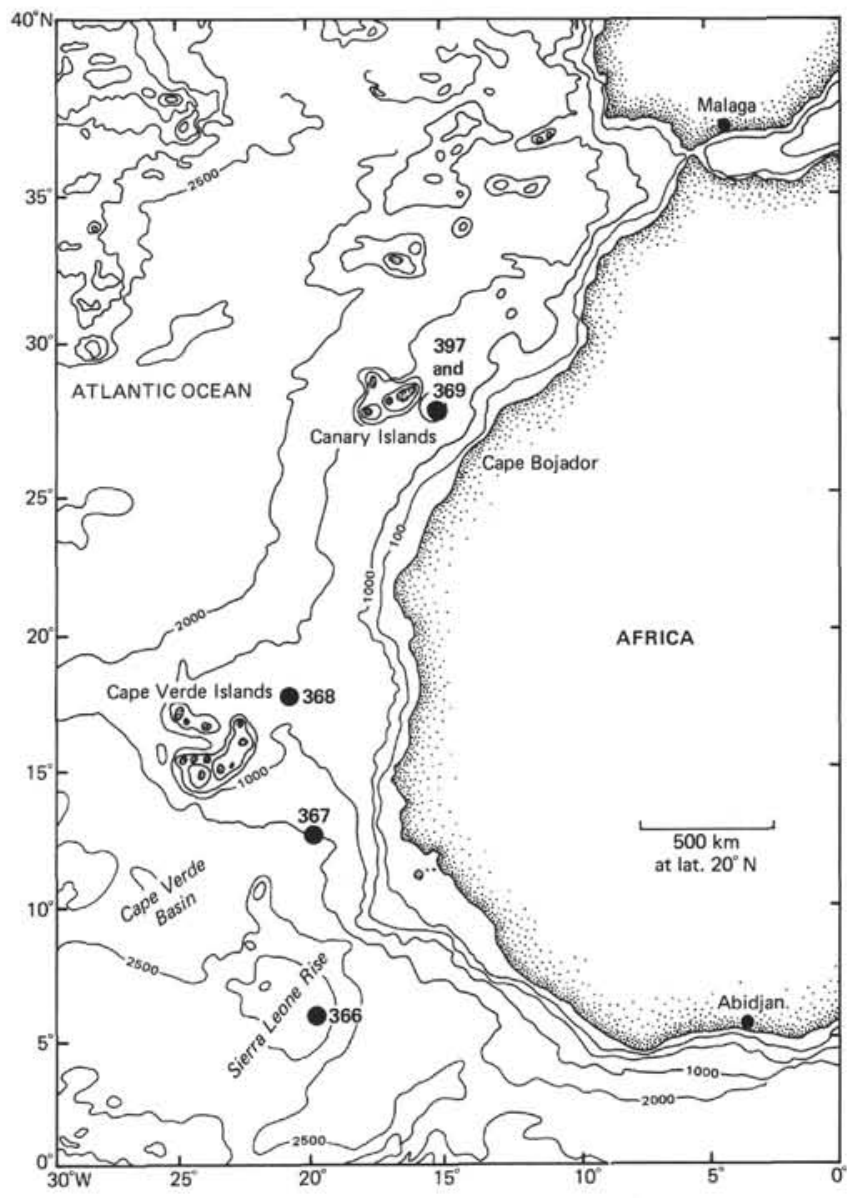

Figure 1. Site 397 (lat $26^{\circ} 50.7^{\prime} \mathrm{N}$, long $15^{\circ} 10.8^{\prime} \mathrm{W}$, water depth $2900 \mathrm{~m}$ ) is located near Site 369 (Leg 41) on the continental slope, but is seaward und 1140 meters deeper. Miocene silicoflagellates are common at Site 369 and occur only as reworked specimens in the Pliocene and Quaternary at Site 397, apparently the result of local erosion and downslope transport. Opal phytoliths in the Pliocene and Quaternary at Site 397 are also present at Sites 366 to 368 of Leg 41. Depth contours in fathoms.

to require normal marine salinity which probably was not often present at Site 397. Instead, upwelling of cool, nutrient-rich waters is indicated by the common silicoflagellates and diatoms of Cores 2 to 21 . Silicoflagellates and diatoms are not present in Miocene Cores 52 to 98 of Hole 397 or Cores 4 to 32 of Hole 397A, probably because Site 397 was offshore beyond the area of coastal upwelling which at nearby Site 369 carried high nitrate and dissolved silica concentrations to the surface during the middle Miocene. 


\begin{tabular}{|c|c|c|c|c|c|}
\hline Age & Zone & Subzone & \multicolumn{2}{|c|}{397} & $397 \mathrm{~A}$ \\
\hline \multirow{5}{*}{ 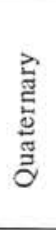 } & \multicolumn{2}{|l|}{ Emiliania huxleyi } & \multicolumn{2}{|c|}{$2-1$} & \\
\hline & \multirow{2}{*}{$\begin{array}{c}\text { Gephyrocapsa } \\
\text { oceanica }\end{array}$} & Ceratolithus cristatus & \multicolumn{2}{|c|}{$3-5 / 5-2$} & \\
\hline & & Emiliania ovata & \multicolumn{2}{|c|}{$6-4$} & \\
\hline & \multirow{2}{*}{$\begin{array}{l}\text { Crenalithus } \\
\quad \text { doronicoides }\end{array}$} & Gephyrocapsa caribbeanica & \multicolumn{2}{|c|}{$7-5 / 11-5$} & \\
\hline & & Emiliania annula & \multicolumn{2}{|c|}{$13-\mathrm{CC} / 14-5$} & \\
\hline \multirow{8}{*}{ 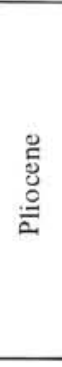 } & \multirow{4}{*}{$\begin{array}{l}\text { Discoaster } \\
\quad \text { brouweri }\end{array}$} & Cyclococcolithina macintyrei & \multicolumn{2}{|c|}{$15-6 / 16-5$} & \\
\hline & & Discoaster pentaradiatus & & & \\
\hline & & Discoaster surculus & \multicolumn{2}{|c|}{$21-4$} & \\
\hline & & Discoaster tamalis & & & \\
\hline & \multirow{2}{*}{$\begin{array}{l}\text { Reticulofenestra } \\
\text { pseudoumbilica }\end{array}$} & Discoaster asymmetricus & & & \\
\hline & & Sphenolithus neoabies & & & \\
\hline & \multirow{3}{*}{$\begin{array}{l}\text { Amaurolithus } \\
\quad \text { tricomiculatus }\end{array}$} & Ceratolithus rugosus & & & \\
\hline & & Ceratolithus acutus & & & \\
\hline \multirow{15}{*}{ 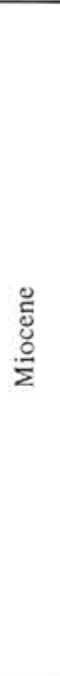 } & & Triquetrorhabdulus rugosus & & & \\
\hline & \multirow{2}{*}{$\begin{array}{l}\text { Discoaster } \\
\quad \text { quinqueramus }\end{array}$} & Amaurolithus primus & & & \\
\hline & & Discoaster berggrenii & \multicolumn{2}{|c|}{$52-2 / 56-2$} & \\
\hline & \multirow{2}{*}{$\begin{array}{l}\text { Discoaster } \\
\text { neohamatus }\end{array}$} & Discoaster neorectus & \multicolumn{2}{|c|}{$57-2$} & \\
\hline & & Discoaster bellus & \multicolumn{2}{|c|}{$? 62-3 / 63-2$} & \\
\hline & \multirow{2}{*}{$\begin{array}{l}\text { Discoaster } \\
\text { hamatus }\end{array}$} & Catinaster calyculus & \multirow{2}{*}{\multicolumn{2}{|c|}{$60-2 / 61-2,64-2 / 70-2$}} & \\
\hline & & Helicosphaera carteri & & & \\
\hline & \multicolumn{2}{|l|}{ Catinaster coalitus } & & & \\
\hline & \multirow{2}{*}{$\begin{array}{l}\text { Discoaster } \\
\text { exilis }\end{array}$} & Discoaster kugleri & $58-2$ & \multirow{2}{*}{$71-2 / 77-2$} & \\
\hline & & Coccolithus miopelagicus & & & \\
\hline & \multicolumn{2}{|c|}{ Sphenolithus heteromorphus } & $78-2 / 80-2$ & \multirow{2}{*}{$83-2 / 87-2$} & \\
\hline & \multicolumn{2}{|c|}{ Helicosphaera ampliaperta } & $92-2 / 96-1$ & & $4-2 / 23-2$ \\
\hline & \multicolumn{2}{|c|}{ Sphenolithus belemnos } & & & $24-1 / 32-3$ \\
\hline & \multirow{2}{*}{$\begin{array}{l}\text { Triquetrorhabdulus } \\
\text { carinatus }\end{array}$} & Discoaster drugii & & & \\
\hline & & Discoaster deflandrei & & & \\
\hline
\end{tabular}

Figure 2. Coccolith zonation of selected Neogene samples from Site 397. Numbers assigned to zonal intervals are core-section numbers. Where several samples are assigned to a zone, the highest and lowest are listed with a slash between. Samples from Cores 58 to 63 are nonsequential because they are from slump deposits. Reworked Cretaceous and Oligocene specimens are common in samples of Cores 78 to 87 and $4 A$ to $32 \mathrm{~A}$. Cores 22 to 51 of Site 397 were not examined.

Sample 397-5-2, 9-11 cm (39 m) contains an atypical assemblage of the Pleistocene Gephyrocapsa oceanica Zone lacking Gephyrocapsa oceanica and dominated by Crenalithus productellus and Gephyrocapsa caribbeanica. The next deeper Sample 397-6-4, 59-61 $\mathrm{cm}(52 \mathrm{~m})$ contains both $G$. oceanica and $G$. caribbeanica along with Emiliania annula and E. ovata, a representative assemblage of the Emiliania ovata Subzone (Bukry, 1975a). Cyclococcolithina macintyrei is abundant in Cores 14 to 16; it is meager in number in Core 13 in the upper Emiliania annula Subzone. Discoasters are common in Pliocene Cores 15 to 21 . The PliocenePleistocene boundary as determined by extinction of discoasters (Ericson and Wollin, 1962; Ericson et al., 1963; Riedel et al., 1963; Bandy and Wilcoxon, 1970) is between two samples from Cores 14 and 15 . Whereas Discoaster brouweri is especially common in Sample 397-15-6, 49-51 cm (141 m), which also con- tains rare reworked $D$. deflandrei and $D$. quinqueramus, it is absent in Sample 397-14-5, 69-71 cm (130 $\mathrm{m})$ which contains only rare reworked $D$. variabilis.

Míocene coccoliths from Cores 52 to 96 are abundant and show moderate preservation. Biostratigraphic determinations (Figure 2) are tentative because bioturbation, winnowing, and slump deposition have created atypical assemblages and assemblages that are out of sequence. For example, an assemblage of the middle Miocene Discoaster kugleri Subzone, containing Coccolithus miopelagicus, Cyclicargolithus floridanus, Discoaster aulakos, D. exilis, and D. kugleri in Sample $397-58-2,19-20 \mathrm{~cm}(552 \mathrm{~m})$, occurs well above the upper Miocene Discoaster neohamatus Zone assemblage in Sample 397-62-3, 15-16 cm (592 m).

Turbidite beds are common in the interval of the Helicosphaera ampliaperta Zone-Sphenolithus heteromorphus Zone boundary, making questionable the ob- 
served ranges of the guide species Cyclococcolithina macintyrei and Helicosphaera ampliaperta. The last $H$. ampliaperta occurs in Core 83, whereas the first rare $C$. macintyrei occurs in Core 87. The possibility of downhole drilling contamination of coccoliths is hard to evaluate or dismiss because various sandy strata were penetrated and could have been cavitated by washing during different coring runs. Reworked Cretaceous coccoliths occur in varying amounts near the zone boundary interval. They are rare in Core 87 , but common in Core 86. The interval from Cores 4 to 32 in Hole 397A is assigned to the lower Miocene Sphenolithus belemnos Zone and Helicosphaera ampliaperta Zone. The rare occurrence of Cyclococcolithina macintyrei in Cores 4 and 5 indicates a level at or near the top of the Helicosphaera ampliaperta Zone. Sample 397A-13-2, 60-61 $\mathrm{cm}(1042 \mathrm{~m})$ is an intact slumped erratic of Lower Cretaceous Nannoconus colomii ooze containing abundant Watznaueria barnesae and pentaliths. In Sample $397 \mathrm{~A}-15-3,21-22 \mathrm{~cm}(1062 \mathrm{~m})$, the indigenous species such as $H$. ampliaperta and Sphenolithus heteromorphus are rare, whereas reworked Cretaceous and Oligocene coccoliths are abundant.

\section{OPAL PHYTOLITHS}

Opal phytoliths (Plates 7 to 9) are the silicified casts of epidermal cells of terrestrial plants, mainly grasses, that have been reported from offshore North Africa in modern dustfalls and from Quaternary deep-sea cores (Kolbe, 1955, 1957; Folger et al., 1967; Folger, 1970). Nomenclature for opal phytoliths is unsettled. The shapes of phytoliths from living and fossil assemblages may or may not be restricted to a given species or genus (Smithson, 1958). Therefore, application of linnean taxonomy would be artificial because it would group single skeletal types under one name. Ehrenberg's original linnean system of 90 species has been summarized and revised (Deflandre, 1963) and expanded into a system of parataxa (Dumitrică, 1973a). Different plant organs, such as skeletal parts, can be given linnean names according to the International Code of Botanical Nomenclature. Descriptive terminology would be equally useful because opal phytoliths are secondary casts, and the few fundamental forms are duplicated in widely separated areas; compare assemblages from Australia (Baker, 1959); U.S.A. (Twiss et al., 1969); Mediterranean Sea (Dumitrică, 1973a); and Atlantic Ocean (Folger et al., 1967). Also, several types of opal phytoliths can be produced by a single leaf at different cell levels (Jones, 1964; Twiss et al., 1969). Some form of descriptive terminology should be used for fossil assemblages. Several systems have been started; the usage of Twiss et al. (1969) is applied here (Figure 3). The system should include major form groups and simple descriptive names for distinctive members that can be incorporated into a simple key for wide application.

Zea mays, i.e., Indian Corn, is native to the Western Hemisphere. It produces several morphotypes of panicoid (dumbbell-shaped) and elongate phytoliths (Twiss et al., 1969). The Pliocene phytolith assemblage

\begin{tabular}{|c|l|l|}
\hline Form & \multicolumn{1}{|c|}{ Class } & \multicolumn{1}{c|}{ Environment or Source } \\
\hline & Festucoid & Humid vegetation \\
\hline & Chloridoid & Short grasses and bamboo \\
\hline & Panicoid & Tall grasses of prairie \\
\hline & Elongate & Ubiquitous, from interstomatal cells \\
\hline
\end{tabular}

Figure 3. Summary of an opal phytolith classification based on Smithson (1958) and Twiss et al. (1969). Agrostoid, Chloridoid, and Nardoid classes were not encountered in core material from Site 397 because their grasses were excluded from the area of provenance or they are more susceptible to dissolution than other classes.

from offshore North Africa at Site 397 contains the same panicoid morphotypes as modern Zea mays. Therefore, particular morphotypes that duplicate those of a native American plant can be produced by the tall grasses of Africa. This is an example of the limited biostratigraphic value of the common forms of opal phytoliths.

Strong trade winds that sweep North Africa may carry opal phytoliths and fresh-water diatoms far out to sea (Folger, 1970) where they settle and are preserved in marine sediment. Opal phytoliths and associated fresh-water diatoms occur at Site 397 in several sediment cores, at least as old as late Pliocene (Figure 4). They are a minor constituent in the acid residues used for silicoflagellate studies, but their presence suggests similar terrestrial vegetation and wind conditions for North Africa between late Pliocene and modern times. Site 397 lies at the northern edge of the modern Atlantic marine area of phytolith concentration. The most common occurrences are in deeper Pliocene and Quaternary Cores 11 and 21. This could reflect more easterly wind patterns or a more northerly grass source.

Quaternary Core 1 at southerly Site 368 contains sparse elongate and dumbbell-shaped phytoliths and a fresh-water diatom Melosira granulata. Pliocene Core 4 at the same site contains only opal phytoliths. Sites 366 and 367 (Figure 1) also contain opal phytoliths in the Quaternary cores. Opal phytoliths in a marine core of Miocene sediment from the Mediterranean Sea (Dumitrică, 1973a; Hajos, 1973) are similar in form and diversity to those from the Pliocene and Quaternary at Site 397. The occurrences described above indicate a similar but not necessarily identical source and supply of eolian sediment to the Atlantic Ocean and Mediterranean Sea during the Neogene. 


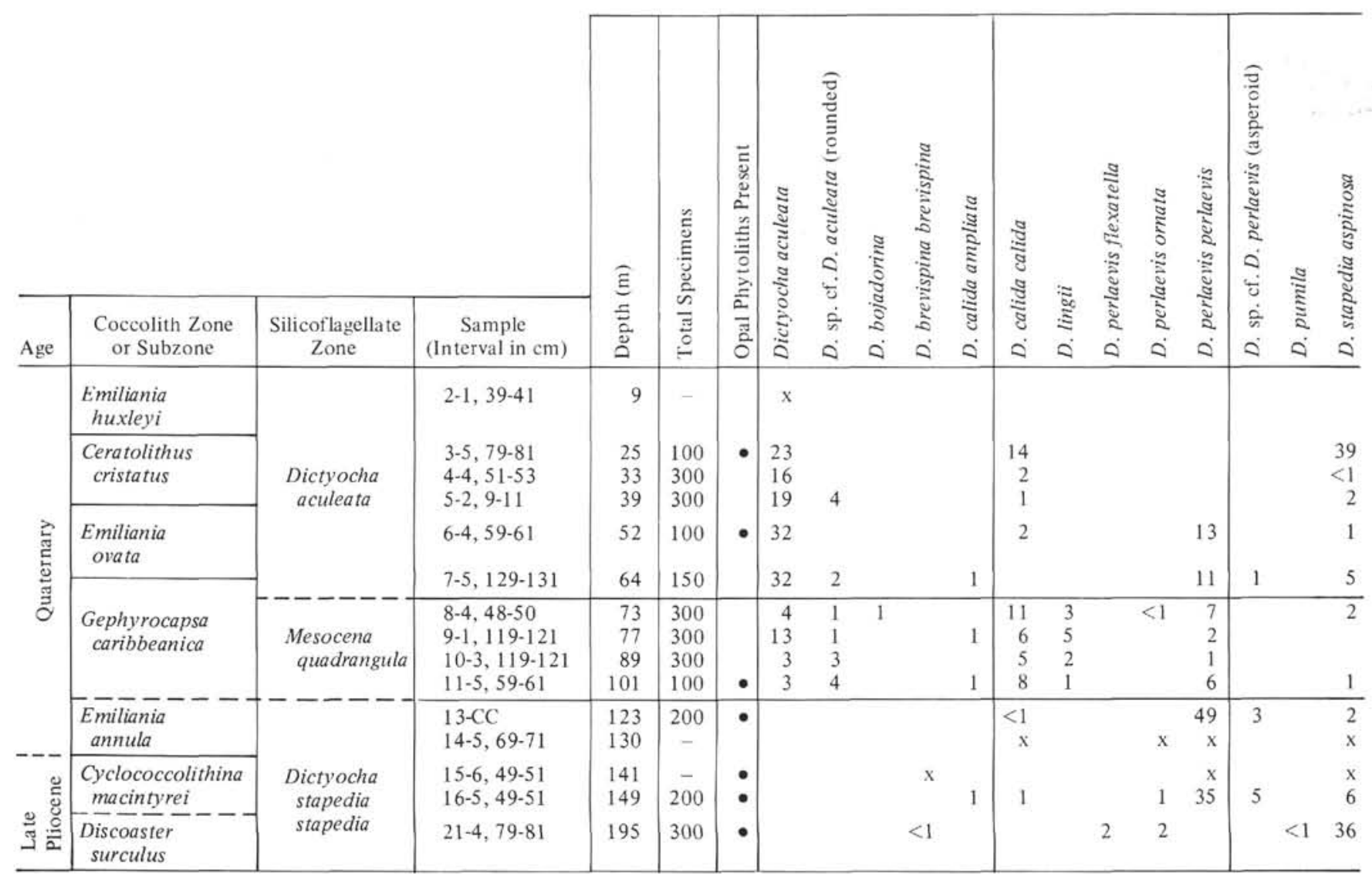

Figure 4. Distribution and abundance of silicoflagellates in Pliocene and Quaternary Cores 2 to 21 at Site 397 are recorded as percents. Opal phytoliths are present, but sparse, in seven of the cores studied. $X=$ silicoflagellate specimens present in an assemblage too sparse to achieve a valid count in a reasonable period of time. Coccolith zonal determinations are from this study (Figure 2).

Because of (1) the usual scarcity of phytoliths in marine sediments, (2) the mixing and winnowing of assemblages during transport by wind or current, (3) the presently nonspecific or ambiguous biologic sources, and (4) differential dissolution, the biostratigraphic value of opal phytoliths presumably would be mainly in local correlations, much as any physical stratigraphic marker such as an ash bed. Opal phytoliths have more potential as an aid to paleoclimatic or provenance studies (Baker, 1959; Jones, 1964; Twiss et al., 1969).

\section{SILICOFLAGELLATES}

\section{Zonation}

Upper Pliocene and Quaternary silicoflagellates are sparse to abundant in acid residues of samples from Cores 2 to 21 of Site 397. Residues from Cores 18 and 24 to 31 are barren or the silicoflagellates are too rare to use for any significant studies. Preservation is generally good throughout. Exceptions are a predominance of ghostly, solution-thinned, or incompletely silicified specimens in Cores 3, 4, 8, and 16. Also, silicoflagellates are notably fragmented in Core 13 , and the count of Mesocena circulus specimens from Core 21 is mostly a composite of fragments, as only two whole specimens were encountered.
Three silicoflagellate biostratigraphic zones are recognized at Site 397. Zonation of the silicoflagellate assemblages uses the accumulating evidence from other Deep Sea Drilling Project sites on the ranges of zonal guide fossils such as Dictyocha aculeata, Mesocena quadrangula, Distephanus boliviensis boliviensis and Dictyocha stapedia stapedia, and also on the ranges of auxiliary guide species such as Dictyocha brevispina brevispina, $D$. lingii, $D$. perlaevis flexatella, D. perlaevis ornata, Mesocena circulus, and Octactis pulchra. Silicoflagellate zones are described below and their relation to coccolith zones, determined for the same samples from Site 397, is shown (Figure 4).

Dictyocha stapedia stapedia Zone (Bukry, 1977a)

The range of Dictyocha stapedia stapedia prior to the appearance of the Quaternary acme of Mesocena quadrangula was used to define the Dictyocha stapedia stapedia Zone for DSDP Leg 37 in the North Atlantic Ocean. At Site 397, the same criteria can be used in the upper Pliocene and lower Quaternary. The assemblages of Site 397 are similar to those of Leg 37, but suggest slightly warmer conditions on the basis of fewer Distephanus speculum speculum and Mesocena circulus, and more of the Dictyocha perlaevis group (Bukry, 1976b). The Distephanus boliviensis group and Mesocena circulus do not usually range above the zone. 


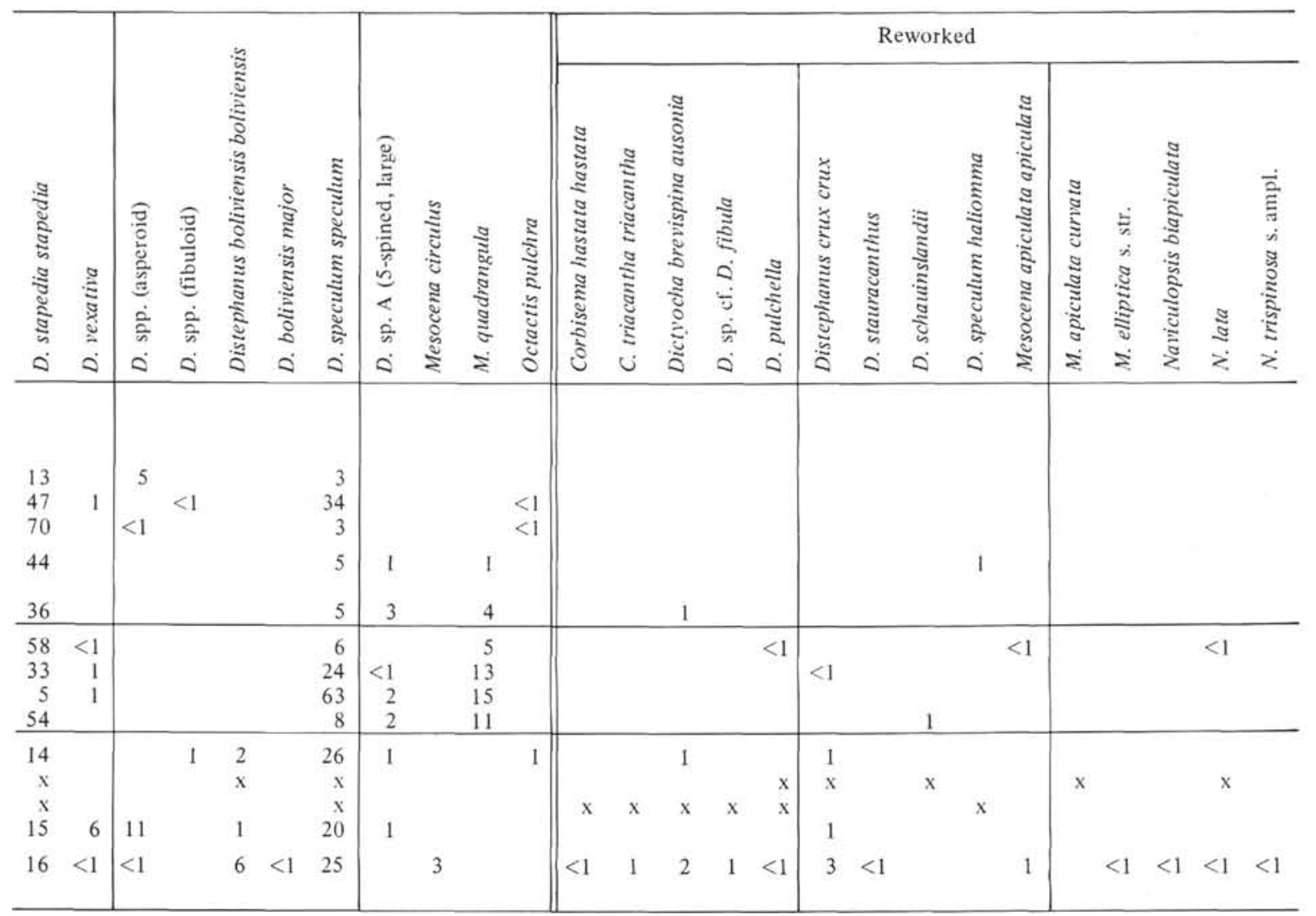

Figure 4. (Continued).

Mesocena quadrangula Zone (Bukry and Foster, 1973)

The Mesocena quadrangula Zone is the interval characterized by the widespread early to middle Quaternary acme of Mesocena quadrangula at low latitudes (Jousé and Mukhina, 1973). The name M. quadrangula replaces the originally used species name $M$. elliptica because of a taxonomic revision (Locker, 1974; Bukry, 1978a). The M. quadrangula Zone of Bukry and Foster (1973), based on the Quaternary acme of $M$. quadrangula, is not equivalent to the $M$. quadrangula Zone of Martini (1971, 1976) which was based on the interval above the first $M$. quadrangula and on the total range of $M$. quadrangula. Because $M$. quadrangula occurs sporadically through the upper Miocene to Quaternary in the Atlantic and Pacific, only the consistent Quaternary acme seems significant for stratigraphic use. The general rise, peak, and fall in numbers of $M$. quadrangula that characterize the acme are illustrated at DSDP Sites 157 and 310 (Bukry, 1976b; in 1978 b) in addition to Site 397 . The Pacific $M$. quadrangula acme ranges from 0.6 to 1.4 m.y., with the peak abundance at 0.85 to 0.95 m.y. (Jousé and Mukhina, 1973). Dictyocha aculeata typically occurs in significant numbers at or just above the acme.

\section{Dictyocha aculeata Zone (Bukry and Foster, 1973)} emended

The common occurrence of Dictyocha aculeata above the Quaternary acme of Mesocena quadrangula is used to identify the Dictyocha aculeata Zone. The lowest occurrence of $D$. aculeata s. str., irrespective of abundance, is consistently within the Quaternary; however, it may be lower Quaternary (Site 397) or middle Quaternary (Site 157). The Dictyocha aculeata Zone of Dumitrică (1973b), defined as the interval above the last $M$. quadrangula, was intended as a similar upper Quaternary biostratigraphic unit. Dumitricǎ's observation that Dictyocha lingii becomes extinct near the same level as $M$. quadrangula is supported by their ranges at Site 397 and at Site 299 (Ling, 1975). Use of the acme termination or the ostensible last occurrence of $M$. quadrangula for the base of the zone may be equally subjective, but the acme can obviate questions of sporadic reworking; such as in Hole 157A (Bukry and Foster, 1973).

\section{Local Reworking}

Late Pliocene and early Quaternary silicoflagellate assemblages of Site 397 contain minor numbers ( 1 to $10 \%$ ) of obviously reworked species, mainly of early or middle Miocene age. These obviously reworked species, such as Distephanus stauracanthus, Mesocena apiculata apiculata, and Naviculopsis lata, have distinctive shapes and either short ranges or well-established extinctions prior to the late Pliocene and Quaternary. Their presence, together with the diatom Annellus californicus (Plate 10, Figures 9, 10) which has a short range at the early to middle Miocene boundary (Ryan 
et al., 1974), indicates erosion and redeposition of biogenic silica from upslope. Early and middle Miocene silicoflagellates are common at Site 369 , which is located just upslope from Site 397 (Bukry, 1977b). The siliceous strata there are only 100 to 200 meters below the sea floor and, presumably, could have been eroded locally during the late Pliocene to supply older species to Site 397. For example, the guide fossil A. californicus occurs in-place in Sample 369A-10-3, 71-72 cm $(131 \mathrm{~m})$. Although Sites 397 and 369 are geographically close, no early or middle Miocene silicoflagellates or diatoms occur in Miocene Cores 52 to 98 at Site 397. Many of the diatoms from the late Pliocene and Quaternary at Site 397 are littoral or benthic species (Plates 9 and 10), which suggests redistribution of diatom skeletons across the continental shelf to this fairly deep site.

\section{SILICOFLAGELLATE TAXONOMY}

\section{Genus CORBISEMA Hanna, 1928}

\section{Corbisema hastata hastata (Lemmermann)}

(Plate 1, Figure 1)

Dictyocha triacantha hastata Lemmermann, 1901, p. 259, pl. 10, fig. 16, 17.

Corbisema hastata (Lemmermann) Frenguelli, 1940, p. 62.

Corbisema hastata hastata (Lemmermann), Bukry, 1976a, p. 892, pl. 4, fig. 9-16.

\section{Corbisema triacantha triacantha (Ehrenberg)}

(Plate 1, Figure 2)

Dictyocha triacantha Ehrenberg, 1844, p. 80.

.Dictyocha triommata Ehrenberg, Ehrenberg, 1854, pl. 33 (XV), fig. 11.

Corbisema triacantha (Ehrenberg) Hanna, 1931, p. 198, pl. D, fig. 1. Corbisema triacantha (Ehrenberg), Locker, 1974, p. 634, pl. 1, fig. 10.

Corbisema triacantha triacantha (Ehrenberg), Bukry, 1977b, p. 702, pl. 1, fig. 13-15.

\section{Genus DICTYOCHA Ehrenberg, 1837}

\section{Dictyocha aculeata (Lemmermann)}

(Plate 1, Figures 3, 4)

Dictyocha epiodon Ehrenberg, Ehrenberg, 1854 (in part), pl. 25B (IV), fig. 10.

Dictyocha fibula var. aculeata Lemmermann, 1901, p. 261, pl. 11, fig. I, 2.

Dictyocha fibula Ehrenberg s. 1., Martini, 1971 (in part), p. 1696, pl. i, fig. 5.

Dictyocha aculeata (Lemmermann), Dumitrică, 1973c, p. 907, pl. 9 , fig. 5-10.

Dictyocha epiodon Ehrenberg, Bukry and Foster, 1973, p. 826, pl. 2, fig. 7,8 .

Dictyocha aculeata (Lemmermann), Dumitricà, 1973b, p. 849, pl. 4, fig. 9-11.

Dictyocha epiodon Ehrenberg, Poelchau, 1976, p. 170, pl. 1, fig. e, f; pl. 4, fig. 2 d.

Dictyocha aculeata (Lemmermann), Martini, 1976 (in part), p. 442, pl. 1, fig. 2, (not pl. 2, fig. 3a, b, ?rhombic ring, sp. indet.).

Remarks: Dictyocha aculeata s. str. characterizes the Quaternary in tropical and temperate areas. Because it usually has a spired and canted apical structure, it shows affinities to $D$. stapedia stapedia. It is distinguished by an octagonal basal ring bearing peripheral pikes at the inter-spine corners. Transitional forms between the two species appear to be rounded or incompletely octagonal and lack the full set of corners and pikes. These specimens are tabulated as $D$. sp. cf. $D$. aculeata (rounded) and could contribute some uncertainty about the lower range of the species. Identification criteria and hence, stratigraphic range may differ between workers (see Plate 1, Figures 5-9).

\section{Dictyocha bojadorina n. sp. \\ (Plate 1, Figures 10-12)}

Description: Dictyocha bojadorina has a slightly irregular polygonal basal ring bearing eight nearly equant spines. Four axial spines can be distinguished. The ring axes are nearly equant with a slight elongation perpendicular to the apical bar. The bar is long and connected to the ring at one end by a shorter pair of struts than at the other end. The most closely appressed pair of spines on the ring are adjacent to the shorter strut junctions. Inter-spine distances are inequant but regular from specimen to specimen.

Remarks: Dictyocha bojadorina is distinguished from its probable ancestor, $D$. aculeata, by more equant spines, less symmetric ring and spines, and inequant strut pairs. It is distinguished from Miocene D. fibula octagona of Tsumura (1963) by its more polygonal ring, lack of dominant axial spines, more inequant portals, and spines that are much shorter relative to the intra-ring diameter.

Occurrence: Dictyocha bojadorina is rare in the Quaternary at Site 397. It appears to have evolved from the $D$. aculeata lineage near the end of the Mesocena quadrangula Zone. Its geographic range is unknown.

Size: $35-50 \mu \mathrm{m}$, maximum internal diameter; holotype $39 \mu \mathrm{m}$.

Holotype: USNM 248081 (Plate 1, Figures 10, 11).

Isotype: USNM 248082.

Type locality: Offshore northwest Africa, Sample 397-8-4, 48-50 $\mathrm{cm}(73 \mathrm{~m})$.

\section{Dictyocha brevispina ausonia (Deflandre)}

Dictyocha ausonia Deflandre, 1950, p. 195, fig. 194-196, 199-202.

Dictyocha brevispina ausonia (Deflandre) Bukry, 1977b, p. 697, pl. 1, fig. 17-19.

Dictyocha ausonia Deflandre, Ling, 1972 (in part), p. 160, pl. 25, fig. 9. 10 .

Remarks: Because I consider basal ring form to be a generally stable key to silicoflagellate taxonomy, the rounded apices and small size of Deflandre's type specimen is used to distinguish Dictyocha brevispina ausonia from other asperoid species such as larger $D$. brevispina brevispina or more elongate $D$. pulchella.

\section{Dictyocha brevispina brevispina (Lemmermann)}

Dictyocha fibula var. brevispina Lemmermann, 1901, p. 260; Ehrenberg, 1854 (in part), pl. 21, fig. 42 b; pl. 22, fig. 42 a, b.

Dictyocha brevispina (Lemmermann) Bukry, 1976b, p. 723.

Dictyocha ausonia Deflandre, Martini, 1976 (in part), p. 442, pl. 1, fig. 15, 16, ?17.

\section{Dictyocha calida calida Poelchau}

(Plate 2, Figures 3, 4)

Dictyocha fibula Ehrenberg, Dumitrică, 1973c (in part), p. 906, pl. 5, fig. 3 .

Dictyocha perlaevis Frenguelli, Dumitrică, 1973b (in part), p. 848 , pl. 4, fig. 1.

Dictyocha sp. cf. D. perlaevis delicata Bukry, Bukry, 1976b, p. 724, pl. 2, fig. 1-3.

?Dictyocha sp. cf. D. perlaevis delicata Bukry, Bukry, 1976c, p. 696, pl. 1, fig. 7.

Dictyocha calida Poelchau, 1976, p. 169, pl. 1, fig. c, d; pl. 3, fig. a-f.

\section{Dictyocha calida ampliata n. subsp.}

(Plate 2, Figures 1, 2, 9)

Description: Dictyocha calida ampliata has a short apical bar, sulcate basal ring, and long spines. The major and minor axes of the ring are subequant. The symmetric indentations of the sides at the junctions of the struts give the ring a pinched appearance.

Remarks: Dictyocha calida ampliata is distinguished from D. calida calida by more extreme elongation of the portals. This elongation is best measured by comparing the proportions, along the axis perpendicular to the bar, of the total width of the apical structure between strut-ring junctions (X2) to the total external width of the ring along the axis $(\mathrm{X} 1$ ). The ratio of $\mathrm{X} 1 / \mathrm{X} 2$ (Figure 5 ) for $D$. calida 


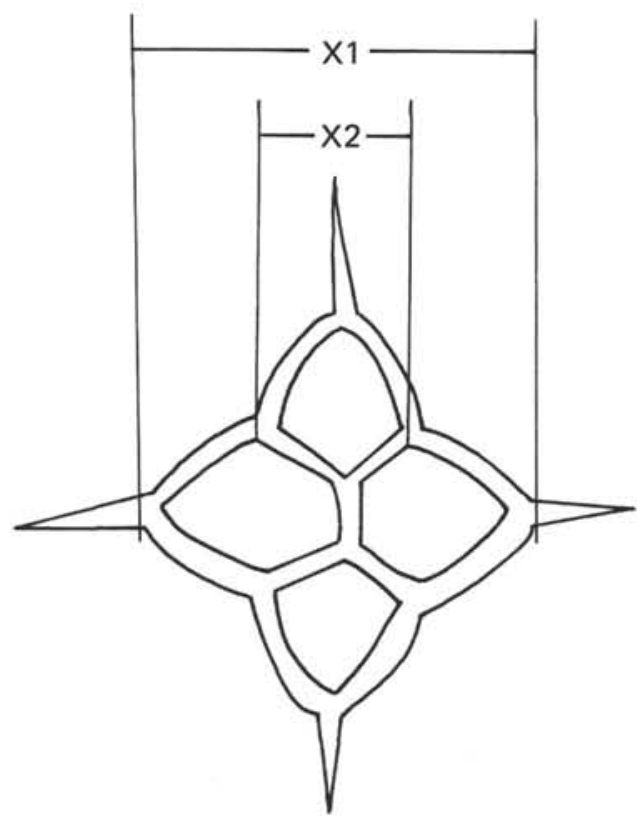

Figure 5. Ratio of the external width of the ring $(X 1)$ to the width of apical structure $(X 2)$, as measured perpendicular to the bar, allows a proportional comparison of elongation of portals between Dictyocha calida calida Poelchau and D. calida ampliata $n$. subsp. $(X 1 / X 2=$ Portal elongation).

ampliata is 2.60 to 2.75 for the type suite; larger ratios are also assigned to the subspecies. The ratio of $\mathrm{X} 1 / \mathrm{X} 2$ for $D$. calida calida is 2.07 to 2.39 for the type suite (see Poelchau, 1976) and 2.14 and 2.33 for the specimens illustrated from DSDP Leg 34 (Bukry, 1976b). Specimens between 2.4 and 2.6 may be visually equivocal, but can be assigned to the new subspecies based on the exclusion of the type suite of $D$. calida calida. A short bar and more angular ring distinguish $D$. calida ampliata from $D$. perlaevis perlaevis. D. constricta is distinguished by its longer bar and irregular outline.

Occurrence: Dictyocha calida ampliata is sparse in the upper Pliocene and lower Quaternary of Site 397. Recorded as " $D$. cf. perlaevis (pinched)," it is fairly common in some Quaternary samples from Site 310 (Bukry, 1978b). It is unknown whether it is still living.

Size: $40-50 \mu \mathrm{m}$, maximum internal diameter; holotype $44 \mu \mathrm{m}$.

Holotype: USNM 248083 (Plate 2, Figure 1).

Isotypes: USNM 248084 and 248085.

Type locality: Offshore northwest Africa, Sample 397-11-5, 59-61 $\mathrm{cm}(101 \mathrm{~m})$.

Dictyocha constricta (Schulz) n. comb.

Dictyocha fibula fa. constricta Schulz, 1928, p. 253, fig. 35a, b.

Dictyocha fibula fa. constricta Schulz, Tsumura, 1963, p. 52, pl. 10 , fig. 3 .

not Corbisema quadralta (Hanna) Deflandre, 1950, p. 135, fig. 140143.

Remarks: Dictyocha constricta is a rarely cited Pliocene and Pleistocene form with an unusually long apical bar and strongly pinched outline. The specimens figured by Schulz and Tsumura are distinguished from $D$. calida ampliata by their long apical bar and prominent basal pikes.

\section{Dictyocha fibula Ehrenberg}

Dictyocha fibula Ehrenberg, 1839, fide Loeblich et al., 1968, p. 90 , pl. 9, fig. 7-12.

Dictyocha fibula Ehrenberg, Martini, 1976 (in part), p. 442, pl. 1, fig. 10.
Dictyocha fibula fibula Ehrenberg, Bukry, 1977b, p. 697, pl. 2, fig. 1. 2.

Remarks: Fairly oval fibuloid forms having basal rings similar to Dictyocha pulchella are listed as $D$. sp. cf. D. fibula. There are no indigenous populations of $D$. fibula (in the sense of Ehrenberg, 1854) in the Pliocene or Pleistocene at Site 397. The need to restrict the species concept of D. fibula (see Bukry, 1977 b) can be seen in several Deep Sea Drilling Project reports. For example, such taxa as Dictyocha fibula augusta, D. aculeata, D. perlaevis perlaevis, D. longispina, and $D$. messanensis have been called $D$. fibula (Martini, 1971, 1976; Bukry, 1975b; Ling, 1975).

\section{Dictyocha lingii Dumitrică \\ (Plate 2, Figures 5-8)}

Dictyocha cf. ausonia Deflandre, Ling, 1970, p. 88, fig. 1, 3.

Dictyocha lingi Dumitricǎ, 1973c, p. 906, pl. 8, fig. 1-7.

Dictyocha lingi Dumitrică, 1973b, p. 848, pl. 3, fig. 4?, 5-7.

Remarks: Dictyocha lingii is a distinctive Quaternary marker species. Its occurrence at Atlantic Site 397 is within the acme of Mesocena quadrangula, a stratigraphic relation that was also reported from DSDP Site 128 and 206 (Dumitrică, 1973b, c). Ling's (1975) illustration from Site 299 has an atypically robust apical structure. Typical specimens occur in the Quaternary at Site 310 (Bukry, 1978b).

The Dictyocha lingii population from Sample 397-8-4, 48-50 cm $(73 \mathrm{~m})$ is distinctive in having a majority of specimens that lack an apical bar. Other structures of these specimens are normal.

Dictyocha longispina (Lemmermann) n. comb.

Dictyocha fibula var. longispina Lemmermann, 1901, p. 260, pl. 10, fig. 26.

not Dictyocha longispina (Lemmermann) Hanna, 1931, p. 200, pl. E, fig. 2,3 .

Dictyocha fibula Ehrenberg s. 1., Martini, 1971 (in part), p. 1698, pl. 1, fig. 4.

Dictyocha fibula Ehrenberg, Ling 1975 (in part), p. 768, pl. 1, fig. 5, 6.

Dictyocha fibula Ehrenberg, Martini, 1976 (in part), p. 442, pl. 1, fig. 9 , pl. 2, fig. 1a, b.

?Dictyocha messanensis Haeckel, Martini, 1976 (in part), p. 443, pl. 1, fig. 9.

Dictyocha sp. cf. D. stapedia aspinosa Bukry, Bukry, 1978b, pl. 1, fig. 9.

Remarks: Dictyocha longispina has an angular rhomboid basal ring with pikes slightly offset from the symmetric strut-ring junctions. Spines are essentially equant and moderate to long. The apical bar is short (approximately a third of the intra-ring major axis) and aligned with the major axis.

Dictyocha longispina is distinguished from $D$. fibula and $D$. perlaevis by its angular rhombic ring and equant spines. It is distinguished from $D$. calida ampliata by the straight sides of its ring and from $D$. stapedia aspinosa by its symmetric strut pattern. $D$. longispina is distinguished from $D$. messanensis by having obvious basal pikes and by lacking an apical spire. Some workers might prefer to treat these two taxa together, as is the case for $D$. aculeata where spired and nonspired specimens are not formally distinguished. But because specimens meeting the definition of $D$. messanensis have not been photographed in recent literature, the significance of $D$. messanensis is doubtful.

Dictyocha longispina occurs in the Pacific Ocean at Sites 66 and 315, and at Sea of Japan Site 302 in the upper Miocene or Pliocene, and questionably in the upper Quaternary (Site 316). The full range is uncertain because it has previously been tabulated as part of a broad $D$. fibula concept. Lemmermann (1901) reported it from the Holocene and Paleocene. The Paleocene reference was probably a specimen of Dictyocha precarentis (Bukry, 1976a) which has the same general morphology but is septate and has a thicker bar. Lemmermann's single illustrated specimen, the holotype, is Holocene.

\section{Dictyocha messanensis Haeckel}

Dictyocha messanensis Haeckel in Peters, 1860 (fide Loeblich et al. 1968 , p. 103 , pl. 17, fig. 24-27.

Dictyocha messanensis Haeckel, 1887, p. 1561.

?Dictyocha fibula var. stapedia Haeckel, Schulz, 1928, p. 254, fig. 39. 
Dictyocha fibula var. messanensis (Haeckel), Tsumura, 1963, p. 53, pl. 10, fig. 10; pl. 23, fig. 11.

not Dictyocha messanensis Haeckel, Poelchau, 1976, p. 173, pl. 1, fig. a, b; pl. 5, fig. a-f.

not Dictyocha messanensis Haeckel, Martini, 1976, p. 443 pl. 1, fig.

9. pl. 2, fig. 2 a, b.

Remarks: Specimens of Dictyocha stapedia stapedia are sometimes tabulated as D. messanensis. According to Haeckel's illustrations of the two species (fide Loeblich et al., 1968), both possess spires. However, they can be distinguished by several criteria. $D$. messanensis has a shorter apical bar, equant instead of inequant spines, symmetric instead of offset strut-ring junctions, and absent or indistinct basal ring pikes instead of regular pikes. These distinctions between the two species are seen in the type illustrations. The offset strut placement is shown for only a few original specimens of $D$. stapedia stapedia, but for none of the D. messanensis (see Bukry, 1976b).

\section{Dictyocha perlaevis flexatella n. sp.}

$$
\text { (Plate 3, Figures 1-3) }
$$

?Dictyocha perlaevis Frenguelli, Dumitrică, 1973b (in part), p. 848, pl. 3, fig. 11.

?Dictyocha perlaevis perlaevis Frenguelli, Bukry, 1976b (in part), p. 724 , pl. 2, fig. 5 ("distorted").

Dictyocha sp. cf. D. perlaevis Frenguelli (Lopsided form), Bukry, 1978b,pl. 1, fig. 5,6 .

Description: Dictyocha perlaevis flexatella has a canted apical bar and nonsymmetric strut junctions. The basal ring pattern is torqued in a counter-clockwise sense in basal view. Four inequant portals result. The apical bar is oriented near the major axis. Major axis spines are moderate and minor axis spines are short. Basal pikes are absent or indistinct.

Remarks: Dictyocha perlaevis flexatella is distinguished from $D$. perlaevis perlaevis by the canted apical bar, nonsymmetric strut pairs, torqued basal ring, and resultant unequal portals. Though it lacks regular symmetry, $D$. perlaevis flexatella is consistent in form from specimen to specimen. The populations at Sites 362 and 397 are seemingly identical.

Occurrence: Dictyocha perlaevis flexatella is known from the upper Pliocene at DSDP Sites 362 and 397 in the South and North Atlantic off Africa. It reaches an abundance of 10 per cent in the assemblage from Sample $362-6-2,49-51 \mathrm{~cm}(86 \mathrm{~m})$, but is only 2 per cent in Sample 397-21-4, 79-81 cm (195 m).

Size: $30-45 \mu \mathrm{m}$, maximum internal diameter; holotype $38 \mu \mathrm{m}$.

Holotype: USNM 248086 (Plate 3, Figure 3).

Isotypes: USNM 248087 and 248088.

Type locality: Offshore northwest Africa, Sample 397-21-4, 79-81 $\mathrm{cm}(195 \mathrm{~m})$.

\section{Dictyocha perlaevis ornata Bukry}

(Plate 3, Figures 4, 5)

Dictyocha fibula Ehrenberg, Bukry and Foster, 1973 (in part), p. 826 , pl. 2 , fig. 9.

?Dictyocha stapedia Haeckel, Dumitrică, 1973b, p. 862, pl. 3, fig. 13 15.

Dictyocha perlaevis ornata Bukry, 1977a, p. 922, pl. 1, fig. 1-6.

Dictyocha perlaevis ornata Bukry, Bukry, 1978b, pl. 1, fig. 7, 8 .

Remarks: Dictyocha perlaevis ornata, which is useful for correlation of the upper Pliocene at Mid-Atlantic Ridge Sites 333 and 335, is most common in the upper Pliocene at Site 397, but is found rarely in higher samples.

\section{Dictyocha perlaevis perlaevis Frenguelli}

(Plate 3, Figures 6-11)

Dictyocha perlaevis Frenguelli, 1951, p. 279, fig. 4b, c.

Distyocha fibula Ehrenberg s. 1., Martini, 1971 (in part), p. 1698, pl. i, fig. 7.

Dictyocha fibula Ehrenberg, Bukry and Foster, 1973 (in part), p. 826 , pl. 3 , fig. 1 .

Dictyocha perlaevis Frenguelli, Dumitrică, 1973b, p. 848, pl. 3, fig. 8?, 9; pl. 4, fig. 2.

Dictyocha fibula perlaevis (Frenguelli) Bukry, 1975b, p. 855, pl. 3, fig. 5 .
Dictyocha perlaevis perlaevis Frenguelli, Bukry, 1976b, p. 724, pl. 2, fig. 4,5 .

Dictyocha fibula Ehrenberg, Martini, 1976 (in part), p. 442, pl. 1, fig. 12.

Dictyocha fibula perlaevis (Frenguelli), Haq and Riley, 1976, p. 681, pl. 2, fig. 4.

Remarks: Dictyocha perlaevis perlaevis is a large typically fibuloid form with a sulcate (scalloped) basal ring. It is common in warm-water assemblages of the Pliocene and Quaternary and is most abundant in Cores 13 and 16 at Site 397. Although D. perlaevis perlaevis is similar to $D$. fibula, it is distinguished by large size, sulcate ring, and broad minor axis portals. $D$. perlaevis perlaevis populations exhibit small numbers of variants in the manner of other species of Dictyocha. These variants include asperoid, cruxoid, deflandroid, and pentagonal forms. Pentagonal forms (Plate 3, Figure 11) may mimic D. pentagona (Schulz, 1928) or D. challengeri (Martini and Müller, 1976) which are probably variants of various different normal taxa (see discussion of D. pentagona in Bukry, 1976a, and also pl. 5, fig. 4 of Dumitrică, 1973c, and pl. 3, fig. 10 of Bukry and Foster, 1973).

\section{Dictyocha pulchella Bukry \\ (Plate 4, Figures 1, 2)}

Dictyocha pulchella Bukry, 1975a, p. 687, pl. 4, fig. 1-3. Dictyocha pulchella Bukry, Bukry, 1977b, pl. 2, fig. 3-6.

Dictyocha pulchella Bukry, Bukry, 1978a, p. 816, pl. 2, fig. 12-16.

Remarks: Dictyocha pulchella is rare and problably reworked at Site 397 because it occurs above its typical range. At other DSDP sites, it is most common in middle and upper Miocene assemblages. It is missing or very rare in upper Pliocene or Quaternary assemblages tabulated for Sites 157, 310, 333, 335, and 362 (Bukry, 1976b, 1977a, 1978b). One specimen from Site 397 is a cruxoid variant which suggests a middle Miocene source because variant populations are most common in the middle Miocene of nearby Sites 369 and 370 .

\section{Dictyocha pumila (Ciesielski)}

(Plate 4, Figure 3)

Dictyocha fibula var. pumila Ciesielski, 1975 , p. 656 , pl. 5, fig. 5-10; pl. 6 , fig. 1,2 ?.

Dictyochapumila (Ciesielski) Bukry, 1978b.

\section{Dictyocha stapedia aspinosa Bukry}

(Plate 4, Figures 4-6)

Dictyocha stapedia aspinosa Bukry, 1976b, p. 724, pl. 2, fig. 6-9.

Remarks: Dictyocha stapedia aspinosa is distinguished from $D$. longispina by the offset locations of the strut-ring junctions. It is distinguished from $D$. stapedia stapedia by the absence of a spire.

\section{Dictyocha stapedia stapedia Haeckel}

Dictyocha stapedia Haeckel, 1887, p. 1561, pl. 101, fig. 10-12. Dictyocha rhombus Haeckel, 1887; Lemmermann, 1901, pl. 11, fig. 3. Dictyocha fibula var. stapedia fa. longispina Schulz, 1928, p. 254, fig. 40.

Dictyocha messanensis Haeckel, Dumitrică, 1973b (in part), p. 849, pl. 4 , fig. 5,7 .

?Dictyocha stapedia Haeckel, Dumitrică, 1973b, p. 849, pl. 4, fig. 4. Dictyocha stapedia stapedia Haeckel, Bukry, 1976b, p. 724, pl. 3, fig. 1-7.

Dictyocha messanensis Haeckel, Martini, 1976 (in part), p. 443, pl. 2 , fig. $2 \mathrm{a}, \mathrm{b}$.

Remarks: Dictyocha stapedia stapedia is characterized by a spire, offset struts, and basal-ring pikes. It is often attributed to D. messanensis, but that species differs in lacking pikes and in having symmetric equant struts. Unspired forms of the D. stapedia group belong to $D$. stapedia aspinosa; unspired forms with possible affinity to $D$. messanensis belong to $D$. longispina. A large form of $D$. stapedia stapedia dominates Pliocene populations of this taxon, a small delicate form dominates the upper Quaternary.

\section{Dictyocha vexativa Bukry \\ (Plate 4, Figures 8-10)}

Dictyochavexativa Bukry, 1978b, pl. 1, fig. 10-14.

Remarks: A few specimens of Dictyocha vexativa, characterized by a short bar and appressed nearly $\mathrm{H}$-shaped apical structure, occur in both the upper Pliocene and Quaternary at Site 397. 
Dictyocha sp. A

(Plate 4, Figure 11)

Remarks: A single specimen of this slightly irregular form occurs in Quaternary Sample 397-4-4, 51-53 cm. It resembles a Quaternary specimen previously illustrated by Dumitrică (1973b, pl. 4, fig. 3) from Pacific Site 206. It differs by more offset struts and canted bar.

Genus DISTEPHANUS Stöhr, 1880

Distephanus boliviensis boliviensis (Frenguelli) (Plate 4, Figure 12; Plate 5, Figure 1)

Dictyocha boliviensis Frenguelli, 1940 (in part), p. 44, fig. 4a.

Dictyocha glabra Frenguelli, 1941, p. 95, pl. 1, fig. 7-9, fide Loeblich et al., 1968, p. 99 , pl. 17 , fig. 1-3.

Dictyocha boliviensis Frenguelli, 1951 (in part), p. 274, fig. 2c, h; fig. $4 \mathrm{~d}, \mathrm{f}$.

Distephanus boliviensis (Frenguelli) Bukry and Foster, 1973, p. 827. pl. 4, fig. 1-3.

Distephanus boliviensis boliviensis (Frenguelli), Bukry, 1975a, p. 688.

Remarks: Distephanus boliviensis boliviensis is most common (6\%) in upper Pliocene Sample 397-21-4, 79-81 cm (195 m). It ranges only into the lower Quaternary and is missing in Cores 2 to 11.

\section{Distephanus boliviensis major (Frenguelli)}

Dictyocha boliviensis Frenguelli, 1940 (in part), p. 44, fig. 4b-d.

Distephanus boliviensis var. major (Frenguelli) Ciesielski, 1975, p. 660. pl. 8, fig. 1-5.

Distephanus boliviensis var. binoculus (Frenguelli) Ciesielski, 1975, p. 660 , pl. 8, fig. 6, 7. (Invalid basionym, ICBN Art. 38, fide Loeblich et al., 1968).

Distephanus boliviensis major (Frenguelli), Bukry, 1975a, p. 688.

\section{Distephanus crux crux Ehrenberg}

(Plate 5, Figure 2)

Dictyocha crux Ehrenberg, 1840, p. 207; Ehrenberg, 1854, pl. 18, fig. 56; pl. 20 (1), fig. 46; pl. 33 (15), fig. 9; pl. 33 (16), fig. 9; pl. 33 (17), fig. 5.

Distephanus crux (Ehrenberg), Locker, 1974 (in part), p. 637, pl. 3 , fig. 8 (not fig. 10).

Remarks: Distephanus crux crux specimens at Site 397 are probably reworked.

\section{Distephanus schauinslandii Lemmermann}

Distephanus schauinslandii Lemmermann, 1901, p. 262, pl. 11, fig. 4, 5.

Distephanus schauinslandii Lemmermann, Ling, 1973, p. 753, pl. 2, fig. 7-9.

Distephanus schauinslandii Lemmermann, Bukry, 1978a, p. 817, pl. 4, fig. 9, 10 .

\section{Distephanus speculum haliomma (Ehrenberg)}

$$
\text { (Plate 5, Figure 5) }
$$

Dictyocha haliomma Ehrenberg, 1844, p. 64, 80; Ehrenberg, 1854, pl. 21, fig. 46.

Dictyocha haliomma Ehrenberg, Locker, 1974, p. 641, pl. 4, fig. 8.

Distephanus speculum haliomma (Ehrenberg) Bukry, 1977b, p. 697 , pl. 2, fig. 10.

Remarks: Distephanus speculum haliomma is typically an upper Oligocene to middle Miocene taxon characterized by irregularly sized apical openings. It is probably reworked at Site 397.

\section{Distephanus speculum speculum (Ehrenberg)}

(Plate 5, Figures 3, 4)

Dictyocha speculum Ehrenberg, 1839, p. 150; Ehrenberg, 1854, pl. 18, fig. 57; pl. 19, fig. 41 ; pl. 21 , fig. 44; pl. 22, fig. 47.

Distephanus speculum (Ehrenberg), Locker, 1974, p. 638, pl. 3, fig. $1-4,7,11$ ?

Distephanus speculum (Ehrenberg), Ciesielski, 1975, p. 660, pl. 9, fig. 11, 12; pl. 10, fig. 1-3.

Remarks: Distephanus speculum speculum specimens from Site 397 are mainly the regular hexagonal form having short to moderate spines, moderate to large apical ring, and pikes present on both rings. Forms having a dominant pair of moderate to long axial spines are sparse. No spineless or swirled variants (Ciesielski, 1975; Bukry, 1976a) occur.

\section{Distephanus stauracanthus (Ehrenberg) (Plate 5, Figure 6)}

Dictyocha stauracanthus Ehrenberg, 1845, p. 56, 57, 76; Ehrenberg, 1854, pl. 33 (14), fig. 5; pl. 33 (15), fig. 10.

Distephanus crux var. octacanthus Desikachary and Maheshwari. 1956, p. 260, fig. 10-13, fide Loeblich et al., 1968, p. 120, pl. 24 , fig. 25-27.

Distephanus octacanthus (Desikachary and Maheshwari) Bukry and Foster, 1973, p. 828, pl. 4, fig. 12; pl. 5, fig. 1 .

Distephanus stauracanthus (Ehrenberg), Dumitrică, 1973b, p. 850 , pl. 6, fig. 14, 15.

Distephanus stauracanthus (Ehrenberg), Locker, 1974, p. 638, pl. 3 . fig. 12.

Remarks: One broken specimen of this lower middle Miocene species occurs in Sample 397-21-4, 79-81 cm and is considered reworked. Dumitricá (1973b) notes that Dictyocha octagona of Tsumura (1963) is a fibuloid form of Distephanus stauracanthus. Ring geometry and stratigraphic occurrence support this view. To help determine why the variant is regular in form and why it may dominate the parent species in marine areas (Dumitrică, 1973b), a vernacular ("fibuloid") or subspecies designation could be maintained.

\section{Distephanus sp. A}

(Plate 5, Figures 7-10)

Remarks: Large, slightly irregular five-spined silicoflagellates in the upper Pliocene and Quaternary of Site 397 may be a lineage of pentagonal survivors of Distephanus boliviensis boliviensis. They are larger than associated specimens of $D$. speculum speculum (which include sparse, like-sized, regular pentagonal variants).

\section{Genus MESOCENA Ehrenberg, 1843}

\section{Mesocena apiculata apiculata (Schulz)}

(Plate 5, Figures 11, 12)

Mesocena oamaruensis apiculata Schulz, 1928, p. 240, fig. 11.

Mesocena apiculata (Schulz), Bukry, 1975b (in part), p. 856, pl. 5, fig. $6,9,($ not 7,8$)$.

\section{Mesocena apiculata curvata Bukry}

(Plate 5, Figure 13)

Septamesocena apiculata (Schulz), Perch-Nielsen, 1975 (in part), p. 689 , pl. 10 , fig. 6.

Mesocena apiculata curvata Bukry, 1976d, p. 849, pl. 2, fig. 15, 16.

Mesocena apiculata curvata Bukry, Bukry, $1978 \mathrm{a}$, p. 818 , pl. 5 , fig. 6,7 .

\section{Mesocena circulus (Ehrenberg)}

(Plate 6, Figures 1, 2)

Mesocena circulus (Ehrenberg) Ehrenberg, 1844, p. 65.

Mesocena circulus (Ehrenberg), Ling, 1972, p. 175, pl. 28, fig. 5, 6.

Mesocena circulus (Ehrenberg), Bukry, 1975b, p. 868, pl. 6, fig. 1, 2.

Remarks: Mesocena circulus occurs only in upper Pliocene Sample $397-21-4,79-81 \mathrm{~cm}$. Assuming this is the top of its natural local range then the disappearance is slightly earlier than that at Sites 310 or 362 . These sites, representing mid-latitude settings contain $M$. circulus at least as high as the Pliocene-Pleistocene boundary.

\section{Mesocena elliptica (Ehrenberg)}

Dictyocha (Mesocena) elliptica Ehrenberg, 1840, p. 208; Ehrenberg, 1854, pl. 20 (1), fig. 44 a, b.

Mesocena elliptica minoriformis Bachmann and Papp, 1968, p. 121, pl. 3, fig. 9.

Mesocena elliptica Ehrenberg, Locker, 1974, p. 634, pl. 2, fig. 4.

Mesocena elliptica Ehrenberg, Bukry, 1978a, p. 819, pl. 6, fig. 6-13. 
Mesocena quadrangula Ehrenberg ex Haeckel (Plate 6, Figures 3-9, 10?)

Mesocena quadrangula Ehrenberg ex Haeckel, 1887, p. 1556; Lemmermann, 1901, pl. 10, fig. 5-7, fide Loeblich et al., 1968, p. 57.

Mesocena quadrangula Ehrenberg ex Haeckel, Martini, 1971, p. 1696, pl. 1, fig. 2.

Mesocena elliptica verrucosa Dumitrică, 1973c, p. 878, pl. 17, fig. 2.

Mesocena quadrangula Ehrenberg ex Haeckel, Bukry, 1978a, p. 819, pl.7, fig. 1-5.

Remarks: Mesocena quadrangula is distinguished from $M$. elliptica by spines that are more nearly equant, noded (blunt or sharp) ornamentation, and typically larger size. The shape of $M$. quadrangula ranges from nearly square to circular; it rarely approaches the typical elliptic $M$. elliptica. Several irregular and pentagonal variants occur at Site 397.

\section{Genus NAVICULOPSIS Frenguelli, 1940}

\section{Naviculopsis biapiculata (Lemmermann)}

Dictyocha navicula biapiculata Lemmermann, 1901, p. 258, pl. 10, fig. 14?, 15.

Dictyocha regularis Carnevale, 1908, p. 35, pl. 4, fig. 28.

Naviculopsis biapiculata (Lemmermann), Bukry, 1975b (in part), p. 856 , pl. 6 , fig. $5,7,8$.

Naviculopsis biapiculata (Lemmermann), Ciesielski, 1975, p. 661, pl. 12, fig. 9?, 10, 11.

Naviculopsis biapiculata (Lemmermann), Bukry, 1978c, p. 787, pl.3, fig. 9, 10 .

Naviculopsisbiapiculata (Lemmermann), Bukry, 1978a, p. 820.

\section{Naviculopsis lata (Deflandre)}

(Plate 7, Figure 1)

Dictyocha biapiculata lata Deflandre, 1932, p. 500, fig. 30, 31 .

Naviculopsis lata (Deflandre) Frenguelli, 1940, p. 61, fig. $11 \mathrm{~h}$.

Naviculopsis robusta Deflandre, Stradner, 1961 , p. 89 , pl. 2, fig. $39-$ 43, 44?, 45.

Naviculopsis lata (Deflandre), Bukry, 1978a, p. 820, pl. 9, fig. 1, 2.

\section{Naviculopsis trispinosa (Schulz)}

Dictyocha navicula trispinosa Schulz, 1928, p. 246, fig. 23a, b. Naviculopsis trispinosa (Schulz), Ling, 1972, p. 190, pl. 31, fig. 7, 8. Naviculopsis trispinosa (Schulz), Bukry, 1975b, p. 857, pl. 7, fig. 5-7.

\section{Genus OCTACTIS Schiller, 1926}

\section{Octactis pulchra Schiller}

(Plate 7, Figures 2, 3)

Octactis pulchra Schiller, 1926, p. 67, fig. C.

Dictyocha octonaria Ehrenberg, Tampieri, 1972, p. 382, pl. 48, fig. la, 1b?, 2ab.

Octactis pulchra Schiller, Bukry and Foster, 1973, p. 829, pl. 6, fig. 11.

Octactis pulchra Schiller, Bukry, 1976b, p. 725, pl. 6, fig. 11.

Octactis pulchra Schiller, Poelchau, 1976, p. 177, pl. 6, fig. h-j.

Remarks: The skeletal form of Octactis pulchra was first described and illustrated by Schiller (1926). Several of Ehrenberg's early drawings of microfossils bear a general resemblance to $O$. pulchra (see in Loeblich et al., 1968: Mesocena bionaria, M. bioctonaria, $M$.? heptagona and $M$.? octogona). Further illustration of uncertainty is seen in comparison of Tsumura's (1963) M. polymorpha bioctonaria fossilis to Locker's (1974) drawings of the M.? octogona holotype and M.? heptagona lectotype. Locker's (1974, pl. 2, fig. 5-8) drawings from some of Ehrenberg's slides show forms that mimic $O$. pulchra, but differ because they have apical plates or basal pikes. Both characters distinguish those specimens from $O$. pulchra which has a simple delicate apical ring and no basal pikes (Poelchau, 1976). Schiller's clear species concept seems an adequate way to solve any historic ambiguities.

The large apical opening of Octactis pulchra distinguishes it from Dictyocha octonaria Ehrenberg (see Loeblich et al., 1968, pl. 19, fig. 13).

\section{ACKNOWLEDGMENT}

I thank James V. Gardner, U.S. Geological Survey, for advice on diverse opal phytolith literature and Dorothy Blackstock, U.S. Geological Survey, for tracking it down. Naja Mikkelsen, Scripps Institution of Oceanography, and John A. Barron, U.S. Geological Survey, provided critical reviews which improved the manuscript. I also thank Oscar E. Weser, Deep Sea Drilling Project, for arranging to have the samples taken for this shore-laboratory study.

\section{REFERENCES}

Bachmann, A. and Papp, A., 1968. Vorkommen und verbreitung der silicoflagellaten im Neogen Österreichs, Gior. Geologia, v. 35, p. 117-126.

Baker, G., 1959. A contrast in the opal phytolith assemblages of two Victorian soils, Australian J. Botany, v. 7, p. 88-96.

Bandy, O. L. and Wilcoxon, J. A., 1970. The Pliocene-Pleistocene boundary, Italy and California, Geol. Soc. Am. Bull., v. 81 , p. $2939-2948$.

Bukry, D., 1973. Low-latitude coccolith biostratigraphic zonation. In Edgar, N. T., Saunders, J. B., et al., Initial Reports of the Deep Sea Drilling Project, v. 15: Washington (U.S. Government Printing Office), p. 685-703.

1975a. Coccolith and silicoflagellate stratigraphy, northwestern Pacific Ocean, Deep Sea Drilling Project Leg 32. In Larson, R. L., Moberly, R., et al., Initial Reports of the Deep Sea Drilling Project, v. 32: Washington (U.S. Government Printing Office), p. 677-701.

1975b. Silicoflagellate and coccolith stratigraphy, Deep Sea Drilling Project Leg 29. In Kennett, J. P., Houtz, R. E., et al., Initial Reports of the Deep Sea Drilling Project, v. 29: Washington (U.S. Government Printing Office), p. 845-872.

1976a. Cenozoic silicoflagellate and coccolith stratigraphy, South Atlantic Ocean, Deep Sea Drilling Project Leg 36. In Hollister, C. D., Craddock, C., et al., Initial Reports of the Deep Sea Drilling Project, v. 35: Washington (U.S. Government Printing Office), p. 885917.

1976b. Silicoflagellate and coccolith stratigraphy, southeastern Pacific Ocean, Deep Sea Drilling Project Leg 34. In Hart, S. R., Yeats, R. S., et al., Initial Reports of the Deep Sea Drilling Project, v. 34: Washington (U.S. Government Printing Office), p. 715-735.

1976c. Comments on some coccoliths and silicoflagellates from Deep Sea Drilling Project Leg 35. In Hollister, C. D., Craddock, C., et al., Initial Reports of the Deep Sea Drilling Project, v. 35: Washington (U.S. Government Printing Office), p. 693-699.

1976d. Silicoflagellate and coccolith stratigraphy, Norwegian-Greenland Sea, Deep Sea Drilling Project Leg 38. In Talwani, M., Udintsev, G., et al., Initial Reports of the Deep Sea Drilling Project, v. 38: Washington (U.S. Government Printing Office), p. 843-855.

1977a. Coccolith and silicoflagellate stratigraphy, central North Atlantic Ocean, Deep Sea Drilling Project Leg 37. In Aumento, F., Melson, W. G., et al., Initial Reports of the Deep Sea Drilling Project, v. 37: Washington (U.S. Government Printing Office), p. 917-928.

1977b. Cenozoic coccolith and silicoflagellate stratigraphy, offshore northwest Africa, Deep Sea Drilling Project Leg 41. In Lancelot, Y., Seibold, E., et al., Initial Reports of the Deep Sea Drilling Project, v. 41: Washington (U.S. Government Printing Office) p. 689-708.

, 1978a. Cenozoic coccolith and silicoflagellate stratigraphy, Deep Sea Drilling Project Leg 44. In Benson, W. E., Sheridan, R. E., et al., Initial Reports of 
the Deep Sea Drilling Project, v. 44: Washington (U. S. Government Printing Office), p. 807-864.

1978b. Cenozoic silicoflagellate and coccolith stratigraphy, southeastern Atlantic Ocean, Deep Sea Drilling Project Leg 40. In Bolli, H. M., Ryan, W. B. F., et al., Initial Reports of the Deep Sea Drilling Project, v. 40: Washington (U. S. Government Printing Office), p. 635650 .

1978c. Cenozoic silicoflagellate and coccolith stratigraphy, northwestern Atlantic Ocean, Deep Sea Drilling Project Leg 43, In Benson, W.E., Sheridan, R.E., et al., Initial Reports of the Deep Sea Drilling Project, v. 43: Washington (U.S. Government Printing Office), p. 775-806.

Bukry, D. and Foster, J. H., 1973. Silicoflagellate and diatom stratigraphy, Leg 16, Deep Sea Drilling Project. In van Andel, T. H., Heath, G. R., et al., Initial Reports of the Deep Sea Drilling Project, v. 16: Washington (U.S. Government Printing Office), p. 815-871.

Carnevale, P., 1908. Radiolarie e Silicoflagellati di Bergonzano (Reggio Emilia), Mem. R. Ist. Veneto Sci., Let. ed Arti, Venezia, v. 28, p. 1-39.

Ciesielski, P. F., 1975. Biostratigraphy and paleoecology of Neogene and Oligocene silicoflagellates from cores recovered during Antarctic Leg 28, Deep Sea Drilling Project. In Hayes, D., Frakes, L. A., et al., Initial Reports of the Deep Sea Drilling Project, v. 28: Washington (U.S. Government Printing Office), p. 625-691.

Deflandre, G., 1932. Sur la systématique des Silicoflagellés, Soc. Bot. France Bull., v. 79, p. 494-506.

1950. Contribution a l'étude des silicoflagellidés actuels et fossiles, Microscopie, v. 2, p. 72-108, 117-142, and 191-210.

1963. Les Phytolithaires (Ehrenberg), Protoplasma, v. 57 , p. $234-259$.

Desikachary, T. V. and Maheshwari, C. L., 1956. Fossil silicoflagellates from Colebrook and Nancoori Islands, Indian Bot. Soc. J., v. 35, p. 257-264.

Dumitricà, P., 1973a. Phytolitharia. In Ryan, W. B. F., Hsü, K. J., et al., Initial Reports of the Deep Sea Drilling Project, v. 13: Washington (U.S. Government Printing Office), p. 940-943.

1973b. Paleocene, late Oligocene and post-Oligocene silicoflagellates in southwestern Pacific sediments cored on DSDP Leg 21. In Burns, P. E., Andrews, J. E., et al., Initial Reports of the Deep Sea Drilling Project, v. 21 : Washington (U.S. Government Printing Office), p. 837 883.

1973c. Miocene and Quaternary silicoflagellates in sediments from the Mediterranean Sea. In Ryan, W. B. F., Hsü, K. J., et al., Initial Reports of the Deep Sea Drilling Project, v. 13: Washington (U.S. Government Printing Office), p. 902-933.

Ehrenberg, C. G., 1839. Über die Bildung der Kreidefelsen und des Kreidemergels durch unsichtbare Organismen, $K$. Preuss. Akad. Wiss. Berlin Ber., Jahrg. 1838, p. 59-148.

1840. 274 Blätter von ihm selbst ausgeführter Zeichnungen von ebenso vielen Arten, K. Preuss. Akad. Wiss. Berlin Ber., Jahrg. 1840, p. 197-219 (Nov.).

1844. Untersuchungen über die kleinsten Lebensformen im Quellenlande des Euphrats und Araxes, so wie über eine an neuen Formen sehr reiche marine Tripelbildung von den Bermuda-Inseln vor., $K$. Preuss. Akad. Wiss. Berlin Ber., Jahrg. 1844, p. 253-275.

1845. Neue Untersuchungen über das kleinste Leben als geologisches Moment., K. Preuss. Akad. Wiss. Berlin Ber., Jahrg. 1845, p. 53-87. p. $1-374$.

1854. Mikrogeologie: Leipzig, (Leopold Voss), Ericson, D. B. and Wollin, G., 1962. Micropaleontology, Sci. Am., v. 207, no. 1, p. 96-108.

Ericson, D. B., Ewing, M., and Wollin, G., 1963. PliocenePleistocene boundary in deep-sea sediments, Science, v. 139 , p. $727-737$.

Folger, D. W., 1970. Wind transport of land-derived mineral, biogenic, and industrial matter over the North Atlantic, Deep-Sea Res., v. 17, p. 337-352.

Folger, D. W., Burckle, L. H., and Heezen, B. C., 1967. Opal phytoliths in a North Atlantic dust fall, Science, v. 155, p. 1243-1244.

Frenguelli, J., 1940. Consideraciones sobre los sílicoflagelados fósiles, Mus. La Plata Rev., Paleontol., v. 2, no. 7, p. 37-112.

1941. Silicoflagellados y Radiolarios del Trípoli del valle de Til-til (Chile) Nota preliminar, $L a$ Plata Univ. Nac., Inst. Mus. La Plata, Notas, Paleontol. no. 28 , v. 6, p. $93-100$.

1951. Silicoflagelados del Trípoli de Mejillones (Chile), Physis (Buenos Aires), v. 20, p. 272-284.

Haeckel, E. H. P. A., 1887. Cannorrhaphida, Challenger Rept., v. 18, p. 1546-1569.

Hajos, M., 1973. The Mediterranean diatoms. In Ryan, W. B. F., Hsü, K. J., et al., Initial Reports of the Deep Sea Drilling Project, v. 13: Washington (U.S. Government Printing Office), p. 944-969.

Hanna, G. D., 1931. Diatoms and silicoflagellates of the Kreyenhagen shale, California Div. Mines State Mineral. Rept., v. 27, p. 187-201.

Haq, B. U. and Riley, A., 1976. Antarctic silicoflagellates from the southeast Pacific, Deep Sea Drilling Project Leg 35. In Hollister, C. D., Craddock, C., et al., Initial Reports of the Deep Sea Drilling Project, v. 35: Washington (U.S. Government Printing Office), p. 673-691.

Hecht, A. D., 1976a. Size variations in planktonic foraminifera: implications for quantitative paleoclimatic analysis, Science, v. 192, p. 1330-1332.

Hecht, A. D., 1976b. An ecologic model for test size variation in Recent planktonic foraminifera: applications to the fossil record, J. Foram. Res., v. 6, p. 295-311.

Jones, R. L., 1964. Note on occurrence of opal phytoliths in some Cenozoic sedimentary rocks, J. Paleontol., v. 38, p. 773-775.

Jousé, A. P. and Mukhina, V. V., 1973. The Mesocena elliptica Ehr. Zone in the Pleistocene sediments of the Pacific Ocean, Oceanology (AGU Translation), v. 13, p. 386-394.

Kolbe, R. W., 1955. Diatoms from equatorial Atlantic cores, Rept. Swedish Deep-Sea Exped., v. 7, p. 150-184.

1957. Fresh-water diatoms from Atlantic deep-sea sediments, Science, v. 126, p. 1053-1056.

Lemmermann, E., 1901. Silicoflagellatae, Deutsche. Bot. Gesell. Ber., v. 19 , p. $247-271$.

Ling, H. Y., 1970. Silicoflagellates from central North Pacific core sediments, Am. Paleontol. Bull., v. 58, p. 85-129.

, 1972. Upper Cretaceous and Cenozoic silicoflagellates and ebridians, Am. Paleontol. Bull., v. 62, p. 135-229.

1973. Silicoflagellates and ebridians from Leg 19. In Creager, J. S., Scholl, D. W., et al., Initial Reports of the Deep Sea Drilling Project, v. 19: Washington (U.S. Government Printing Office), p. 751-775.

1975. Silicoflagellates and ebridians from Leg 31. In Ingle, J. C., Karig, D. E., et al., Initial Reports of the Deep Sea Drilling Project, v. 31: Washington (U.S. Government Printing Office), p. 763-777. 
Locker, S., 1974. Revision der Silicoflagellaten aus der Mikrogeologischen Sammlung von C. G. Ehrenberg, Eclog. Geol. Helv., v. 67, p. 631-646.

Loeblich, A. R. 3d, Loeblich, L. A., Tappan, H., and Loeblich, A. R., Jr., 1968. Annotated index of fossil and recent silicoflagellates and ebridians with descriptions and illustrations of validly proposed taxa: Geol. Soc. Am. Mem. 106,p. 319.

Martini, E., 1971. Neogene silicoflagellates from the equatorial Pacific. In Winterer, E.L., Riedel, W.R., et al., Initial Reports of the Deep Sea Drilling Project, v. 7, Part 2: Washington (U.S. Government Printing Office), p. 16951708 .

1976. Neogene and Quaternary silicoflagellates from the central Pacific Ocean (DSDP Leg 33). In Jackson, E. D., Schlanger, S. O., et al., Initial Reports of the Deep Sea Drilling Project, v. 33: Washington (U.S. Government Printing Office), p. 439-449.

Martini, E. and Müller, C., 1976. Eocene to Pleistocene silicoflagellates from the Norwegian-Greenland Sea (DSDP Leg 38). In Talwani, M., Udintsev, G., et al., Initial Reports of the Deep Sea Drilling Project, v. 38: Washington (U.S. Government Printing Office), p. 857-895.

McIntyre, A., Ruddiman, W. F., and Jantzen, R., 1972. Southward penetrations of the North Atlantic Polar Front: faunal and floral evidence of large-scale surface water mass movements over the last 225,000 years, Deep-Sea Res., v. 19, p. 61-77.

Perch-Nielsen, K., 1975. Late Cretaceous to Pleistocene silicoflagellates from the southern southwest Pacific, DSDP Leg 29. In Kennett, J. P., Houtz, R. E., et al., Initial Reports of the Deep Sea Drilling Project, v. 29: Washington (U.S. Government Printing Office), p. 677-721.

Peters, W., 1860. Kurzen Auszug aus einer Abhandlung des Hrn. Dr. Ernst Haeckel über neue, labende Radiolarien des Mittelmeeres und legte die dazu gehörigen Abbildungen vor, K. Preuss. Akad. Wiss. Berlin Mber., Jahrg. 1860 , p. $794-817$.

Poelchau, H. S., 1976. Distribution of Holocene silicoflagellates in North Pacific sediments, Micropaleontology, v. 22, p. 164-193.

Riedel, W. R., Bramlette, M. N., and Parker, F. L., 1963. "Pliocene-Pleistocene" boundary in deep-sea sediments, Science, v. 140, p. 1238-1240.

Ryan, W. B. F., Cita, M. B., Dreyfus Rawson, M., Burckle, L. H., and Saito, T., 1974. A paleomagnetic assignment of Neogene stage boundaries and the development of isochronous datum planes between the Mediterranean, the $\mathrm{Pa}$ cific and Indian Oceans in order to investigate the response of the world ocean to the Mediterranean "salinity crisis," Riv. Ital. Paleontol., v. 80, p. 631-688.

Schiller, J., 1926. Die planktontischen Vegetation des adriatischen Meers.: B. Chrysomonadina, Heterokontae, Cryptomonadina, Eugleninae, Volvocales. 1. Systematischer Teil, Arch. Protistenk, v. 53, p. 59-123.

Schulz, P., 1928. Beiträge zur Kenntnis fossiler und rezenter Silicoflagellaten, Bot. Archiv, v. 21, p. 225-292.

Smithson, F., 1958. Grass opal in British soils, J. Soil Sci., v. 9 , p. $148-154$

Stradner, H., 1961. Über fossile Silicoflagelliden und die Möglichkeit ihrer Verwendung in der Erdölstratigraphie, Erdol Kohle, v. 14, p. 87-92.

Tampieri, R., 1972. Fitoplancton vivente nel Mediterraneo silicoflagellati, Gior. Geol., v. 38, p. 375-394.

Tsumura, K., 1963. A systematic study of Silicoflagellatae, Yokohama Municipal Univ. J., ser. C-45, no. 146, p. 1-84.

Twiss, P. C., Suess, E., and Smith, R. M., 1969. Morphological classification of grass phytoliths, Soil Sci. Soc. Am. Proc., v. 33, p. 109-115. 
PLATE 1

Silicoflagellates From Site 397

All figures magnified $800 \times$; scale bar equals $10 \mu \mathrm{m}$.

Figure 1 Corbisema hastata hastata (Lemmermann). Sample 397-15-6, 49-51 cm (151 m).

Figure 2 Corbisema triacantha triacantha (Ehrenberg). Sample 397-21-4, 79-81 cm (195 m).

Figures 3,4 Dictyocha aculeata (Lemmermann).

3. Sample 397-5-2, 9-11 cm (39 m); cruxoid.

4. Sample $397-3-5,79-81 \mathrm{~cm}(25 \mathrm{~m})$; normal.

Figure 5-9 Dictyocha sp. cf. D. aculeata (Lemmermann); rounded.

5,9. Sample $397-8-4,48-50 \mathrm{~cm}(73 \mathrm{~m})$.

6. Sample 397-9-1, 119-121 cm (77 m).

7,8. Sample 397-7-5, 129-131 cm (64 m).

Figures 10-12 Dictyocha bojadorina $\mathrm{n}$. sp.

10,11. Holotype, USNM 248081.

Sample 397-8-4, 48-50 cm (73m); apical and basal focus.

12. USNM 248082.

Sample $397-8-4,48-50 \mathrm{~cm}$ (73 m); basal focus. 
PLATE 1
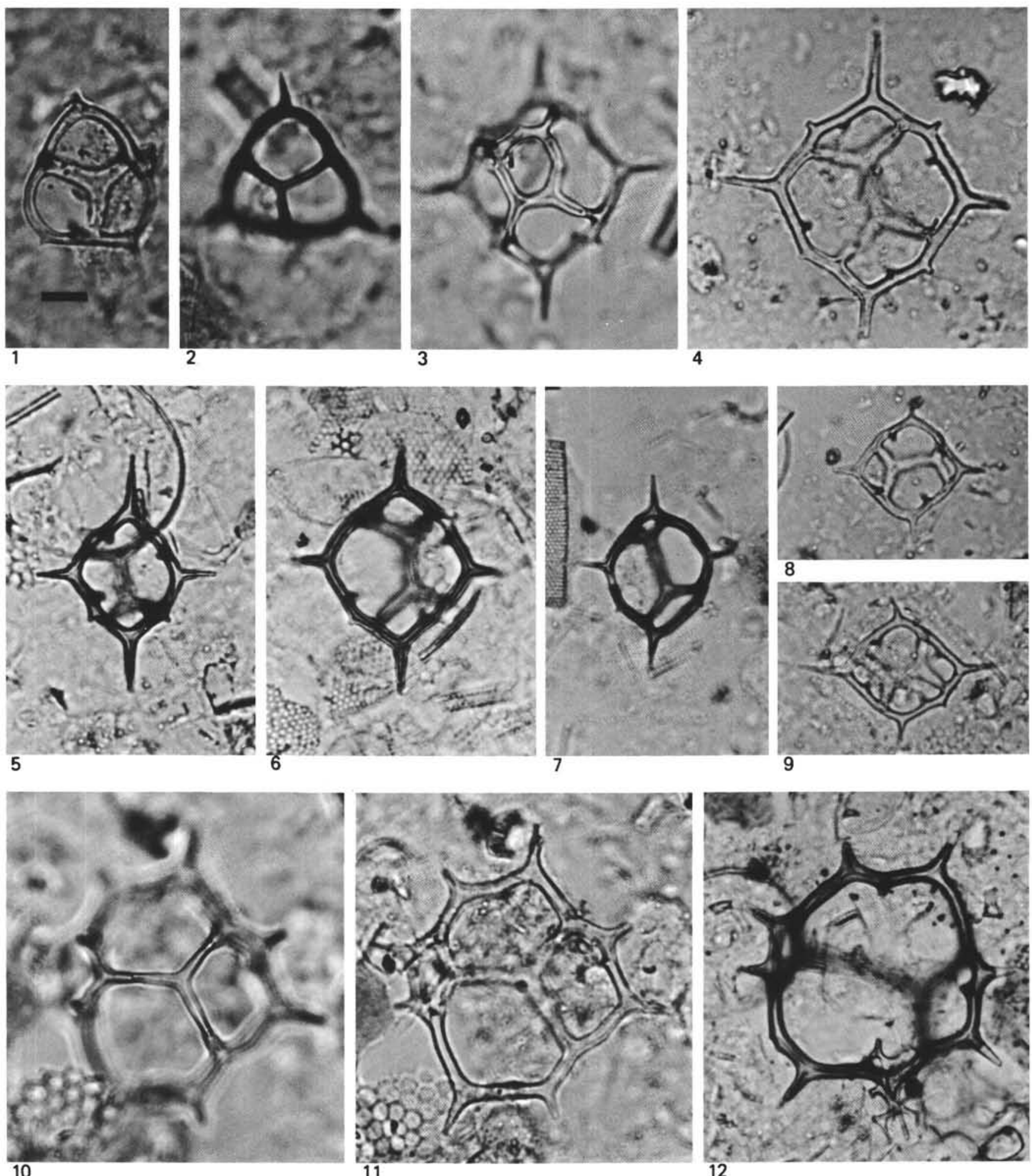
PLATE 2

Silicoflagellates From Site 397

All figures magnified $800 \times$; scale bar equals $10 \mu \mathrm{m}$.

Figures 1,2,9 Dictyocha calida ampliata $\mathrm{n}$. subsp.

1. Holotype, USNM 248083.

Sample 397-11-5, 59-61 cm (101 m).

2. USNM 248084.

Sample 397-16-5, 49-51 cm (149 m).

9. USNM 248085.

Sample 397-9-1, 119-121 cm (77 m).

Figures 3,4 Dictyocha calida calida Poelchau.

3. Sample 397-9-1, 119-121 cm (77 m).

4. Sample $397-8-4,48-50 \mathrm{~cm}(73 \mathrm{~m})$.

Figures 5-8 Dictyocha lingii Dumitrică.

5-7. Sample $397-8-4,48-50 \mathrm{~cm}(73 \mathrm{~m})$.

8. Sample $397-9-1,119-121 \mathrm{~cm}(77 \mathrm{~m})$. 
PLATE 2
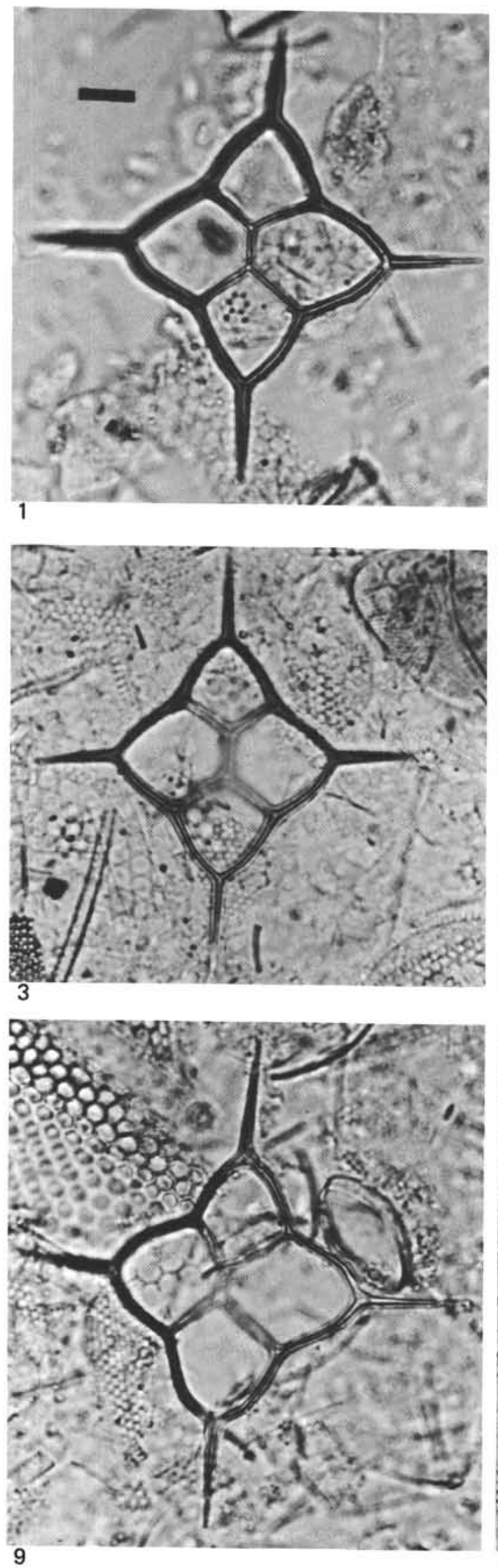
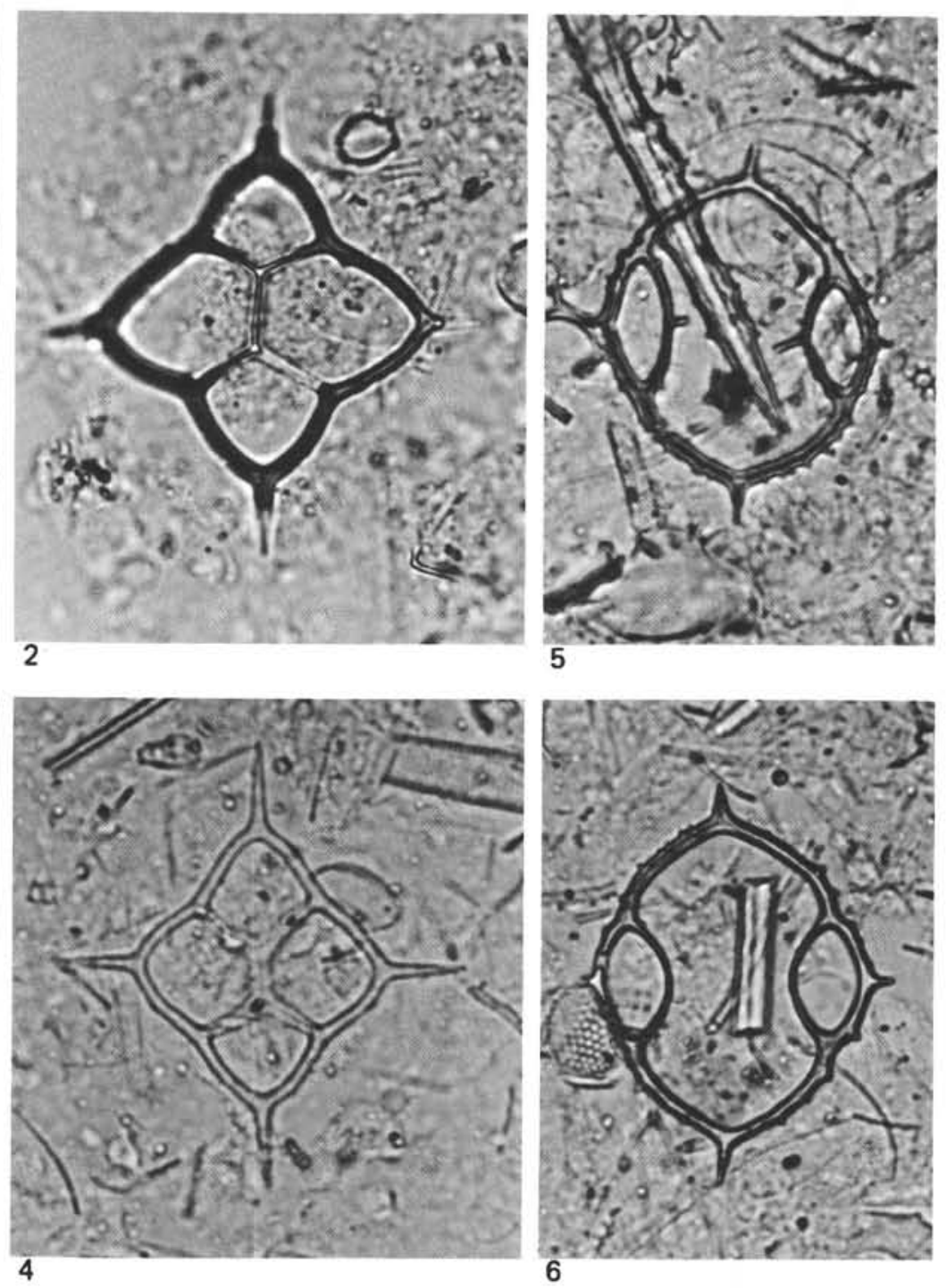

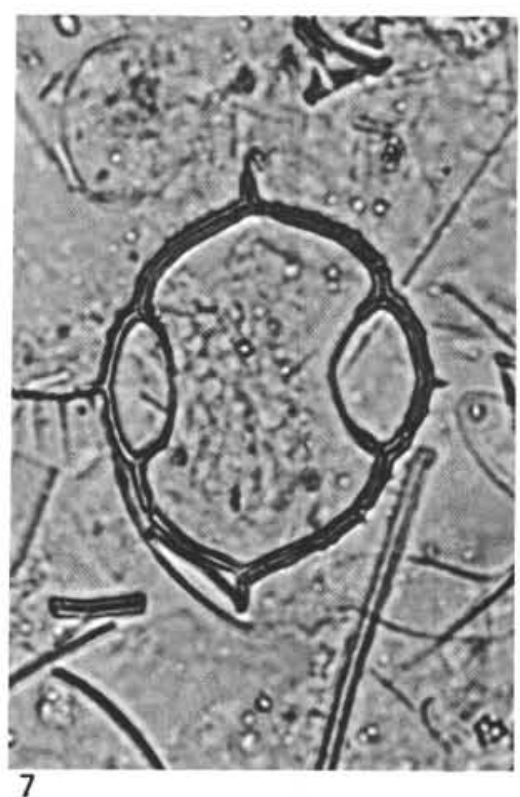


PLATE 3

Silicoflagellates from Site 397.

All figures magnified $800 \times$; scale bar equals $10 \mu \mathrm{m}$.

Figures 1-3 Dictyocha perlaevis flexatella $\mathrm{n}$. subsp. Sample 397-21-4, 79-81 cm (195 m).

1. USNM 248087.

2. USNM 248088.

3. Holotype, USNM 248086.

Figures 4,5 Dictyocha perlaevis ornata Bukry. Sample 397-21-4, 79-81 cm (195 m).

Figures 6-11 Dictyocha perlaevis perlaevis Frenguelli.

6. Sample $397-13$, CC $(123 \mathrm{~m})$; arrowhead variant.

7. Sample 397-13, CC (123 m); large.

8. Sample $397-8-4,48-50 \mathrm{~cm}(73 \mathrm{~m})$; normal

9. Sample $397-16-5,49-51 \mathrm{~cm}(141 \mathrm{~m})$; deflandroid.

10. Sample 397-7-5, 129-131 cm (64 m); curved spines.

11. Sample 397-13, CC (123 m); pentagonal. 


\section{PLATE 3}
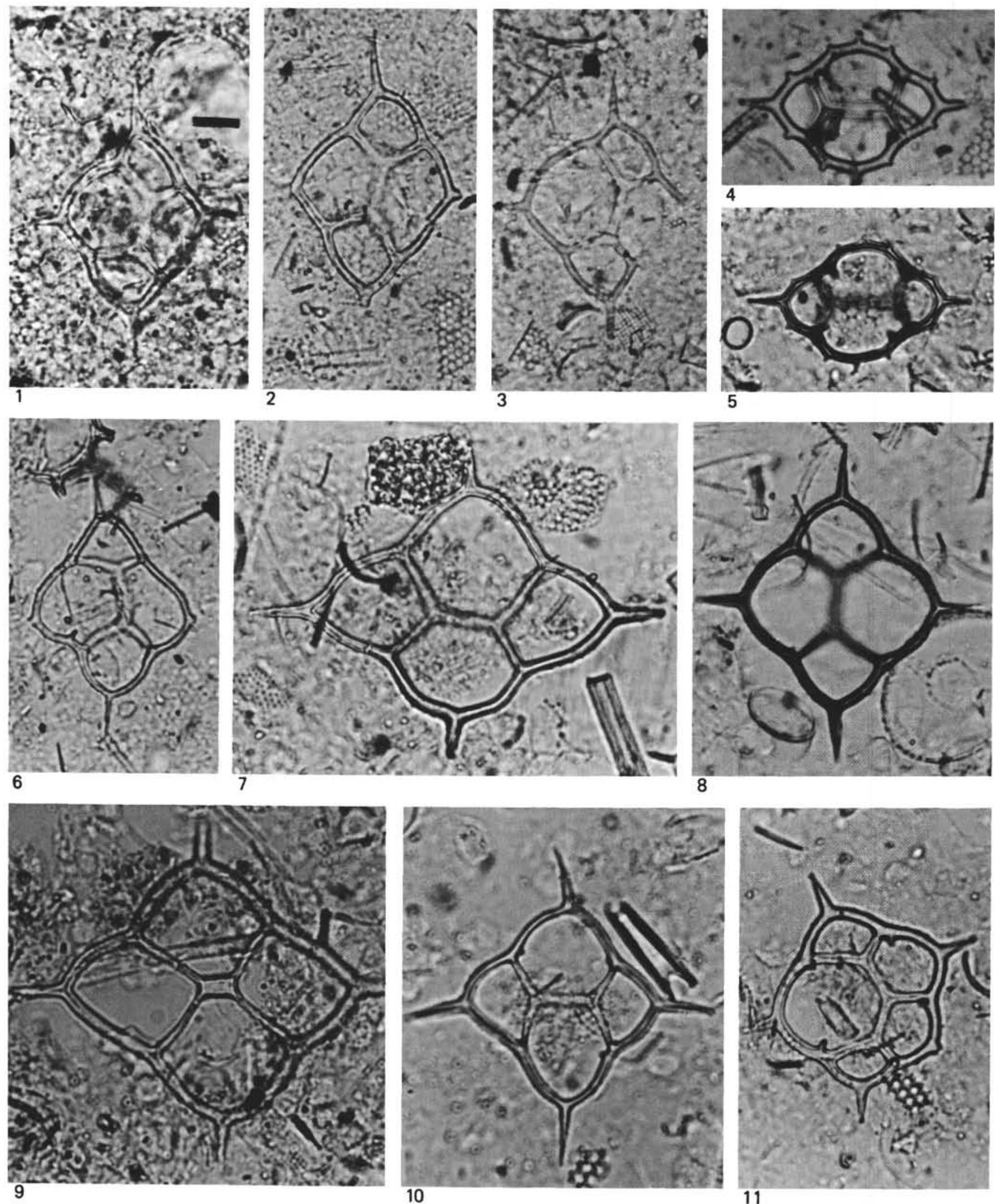
PLATE 4

Silicoflagellates From Site 397

Figures 6,8 magnified $1050 \times$; scale bar equals $10 \mu \mathrm{m}$.

Figures 1-5, 7, 9-12 magnified $800 \times$; scale bar equals $10 \mu \mathrm{m}$.

Figures 1,2 Dictyocha pulchella Bukry.

1. Sample $397-14-5,69-71 \mathrm{~cm}(130 \mathrm{~m})$; normal.

2. Sample $397-21-4,79-81 \mathrm{~cm}(195 \mathrm{~m})$; cruxoid.

Figure 3 Dictyocha pumila (Ciesielski).

Sample 397-21-4, 79-81 cm (195 m).

Figures 4-6 Dictyocha stapedia aspinosa Bukry.

4,5. Sample 397-21-4, 79-81 cm (195 m).

6. Sample $397-4-4,51-53 \mathrm{~cm}(33 \mathrm{~m})$.

Figure 7 Dictyocha stapedia stapedia Haeckel.

Sample 397-5-2, 9-11 cm (39 m).

Figures 8-10 Dictyocha vexativa Bukry.

8. Sample 397-15-6, 49-51 cm (141 m).

9. Sample $397-16-5,49-51 \mathrm{~cm}(149 \mathrm{~m})$.

10. Sample $397-4-4,51-53 \mathrm{~cm}(33 \mathrm{~m})$.

Figure 11 Dictyocha sp. A.

Sample 397-21-4, 79-81 cm (195 m).

Figure 12 Distephanus boliviensis boliviensis (Frenguelli).

Sample 397-13, CC (123 m). 
PLATE 4
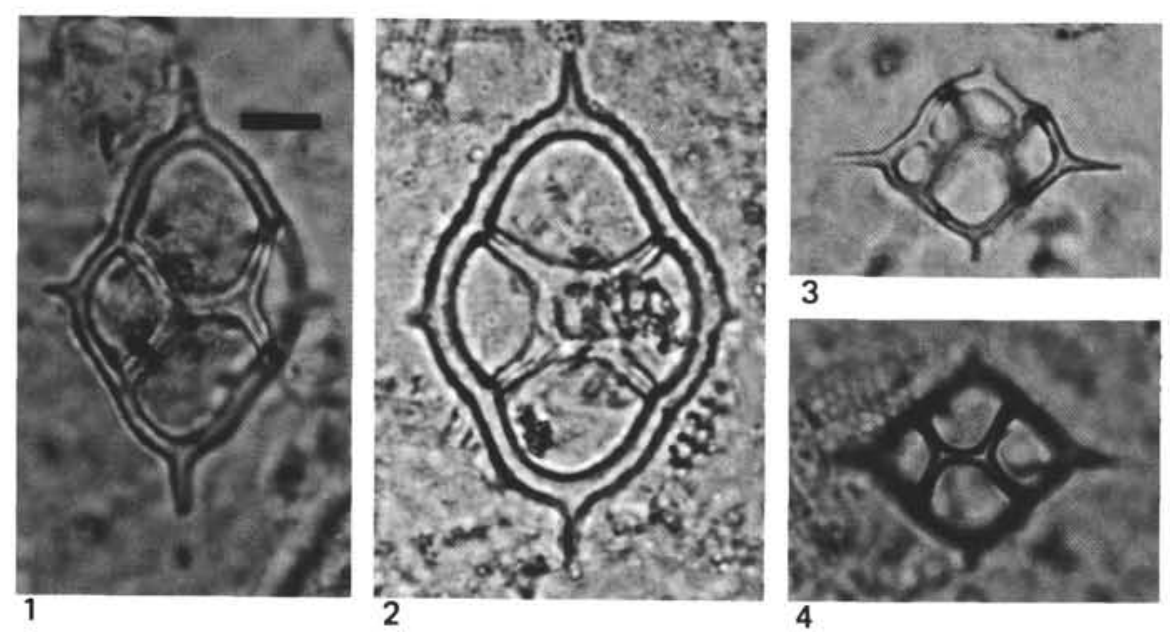

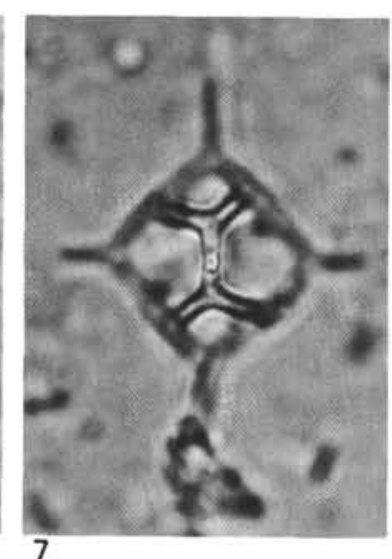

7
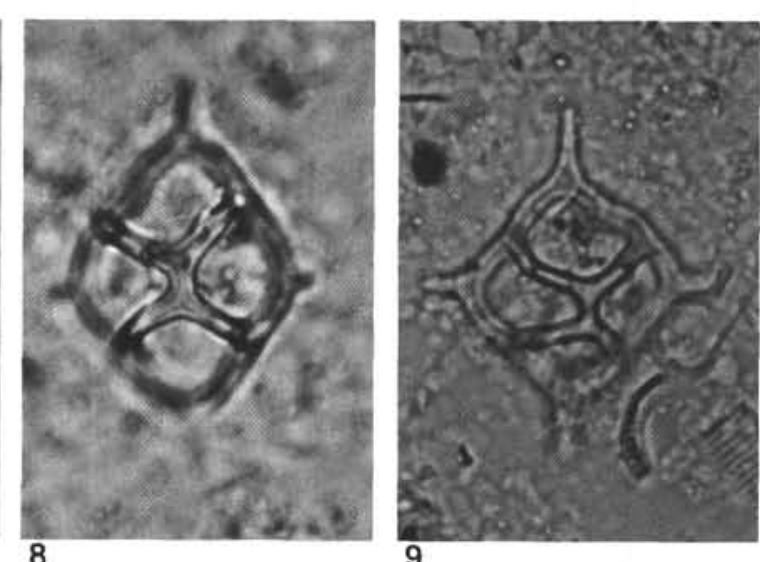
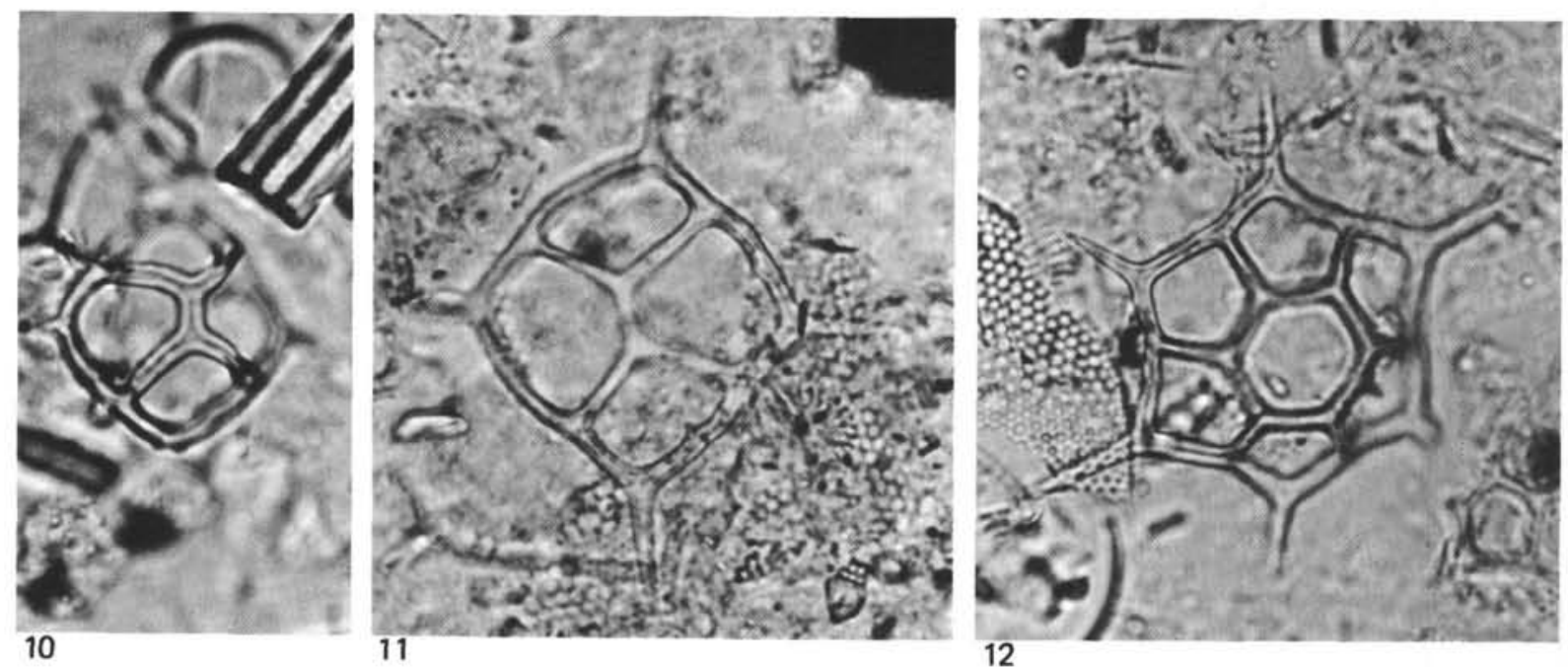


\section{PLATE 5}

Silicoflagellates From Site 397

Figures 1-9,11-13 magnified $800 \times$; scale bar equals $10 \mu \mathrm{m}$.

Figure 10 magnified $400 \times$; scale bar equals $20 \mu \mathrm{m}$.

Figure 1 Distephanus boliviensis boliviensis (Frenguelli). Sample 397-21-4, 79-81 cm (195 m).

Figure 2 Distephanus crux crux (Ehrenberg). Sample 397-11-5, 59-61 cm (101 m).

Figures 3,4 Distephanus speculum speculum (Ehrenberg).

3. Sample 397-10-3, 119-121 cm (89 m).

4. Sample $397-5-2,9-11 \mathrm{~cm}(39 \mathrm{~m})$.

Figure 5

Distephanus speculum haliomma (Ehrenberg). Sample 397-15-6, 49-51 cm (141 m).

Figure $6 \quad$ Distephanus stauracanthus (Ehrenberg). Sample 397-21-4, 79-81 cm (195 m).

Figures 7-10 Distephanus sp. A.
7. Sample $397-13, \mathrm{CC}(123 \mathrm{~m})$.
8. Sample 397-7-5, 129-131 cm (64 m).
9. Sample 397-9-1, 119-121 cm (77 m).
10. Sample $397-6-4,59-61 \mathrm{~cm}(52 \mathrm{~m})$.

Figures 11,12 Mesocena apiculata apiculata (Schulz).

11. Sample 397-21-4, 79-81 cm (195 m).

12. Sample $397-8-4,48-50 \mathrm{~cm}(73 \mathrm{~m})$.

Figure 13 Mesocena apiculata curvata Bukry. Sample 397-14-5, 69-71 cm (130 m). 
PLATE 5

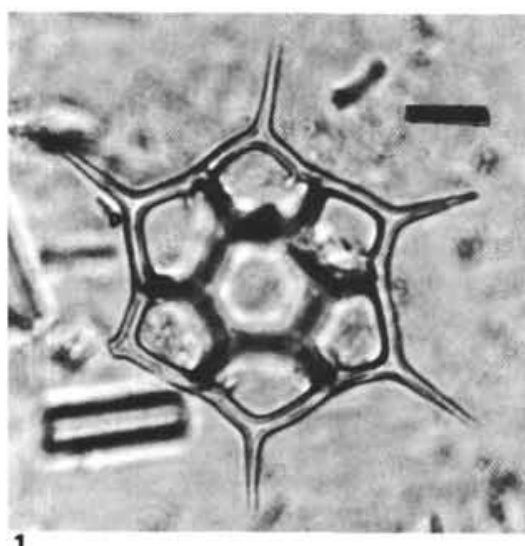

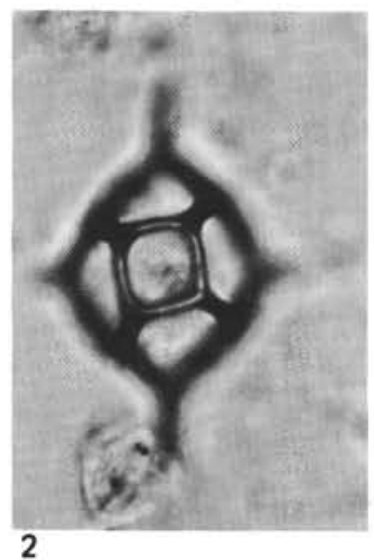
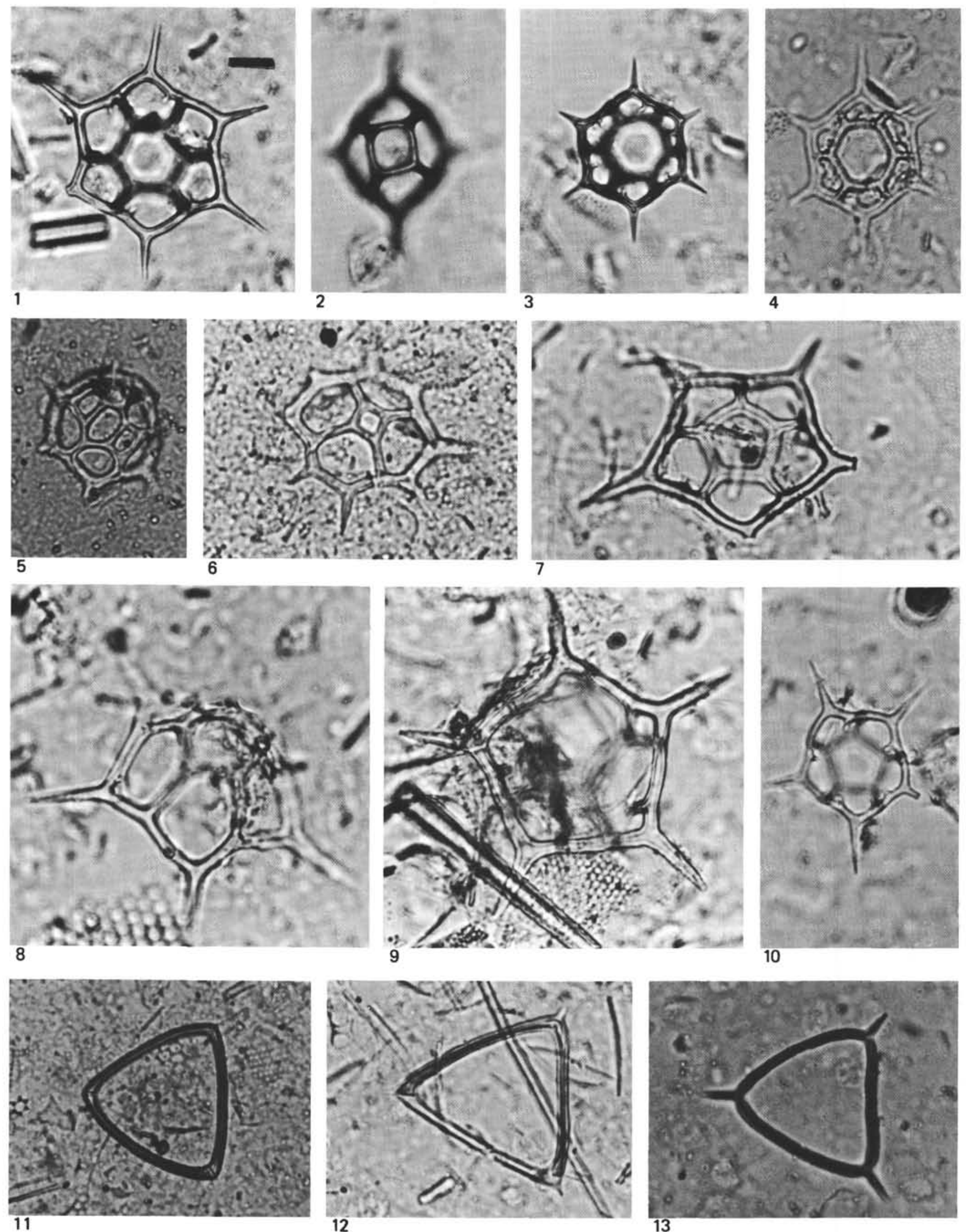
PLATE 6

Silicoflagellates From Site 397

Figures 1-5,7-10 magnified $800 \times$; scale bar equals $10 \mu \mathrm{m}$.

Figure 6 magnified $350 \times$; scale bar equals $20 \mu \mathrm{m}$.

Figures 1,2 Mesocena circulus (Ehrenberg).

Sample 397-21-4, 79-81 cm (195 m).

1. Whole specimen.

2. Fragment.

Figures 3-9 Mesocena quadrangula Ehrenberg ex Haeckel and variants.

3. Sample $397-8-4,48-50 \mathrm{~cm}(73 \mathrm{~m})$; normal.

4. Sample $397-8-4,48-50 \mathrm{~cm}$ (73 m); pentagonal.

5. Sample $397-11-5,59-61 \mathrm{~cm}(101 \mathrm{~m})$; irregular.

6. Sample $397-10-3,119-121 \mathrm{~cm}(89 \mathrm{~m})$; normal.

7. Sample $397-7-5,129-131 \mathrm{~cm}$ (64 m); elliptic, short-spined.

8. Sample $397-11-5,59-61 \mathrm{~cm}(101 \mathrm{~m})$; oblong.

9. Sample 397-9-1, 119-121 cm (77 m); circular.

Figure 10 ?Mesocena quadrangula Ehrenberg ex Haeckel (diodon-like).

Sample 397-7-5, 129-131 cm (64 m); compare to Figure 7. 
PLATE 6
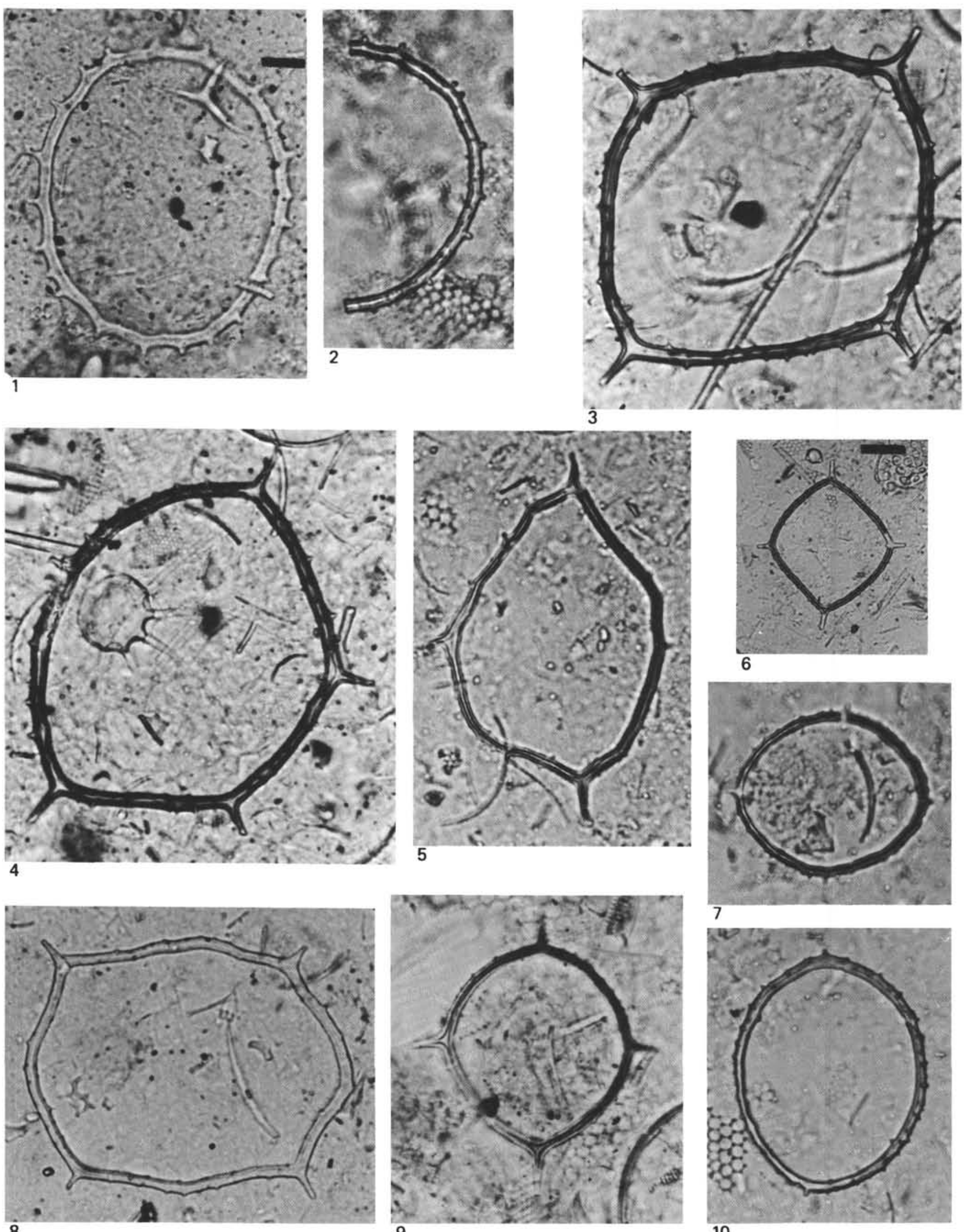


\section{PLATE 7}

Silicoflagellates (Figures 1-8) and Opal Phytoliths

(Figures 9-18) From Site 397

Figures 4,9-18 magnified $1050 \times$; scale bar equals $10 \mu \mathrm{m}$.

Figures 1-3,5-8 magnified $800 \times$; scale bar equals $10 \mu \mathrm{m}$.

Figure $1 \quad$ Naviculopsis lata (Deflandre).

Sample 397-14-5, 69-71 cm (130 m).

Figures 2,3 Octactis pulchra Schiller.

2. Sample 397-13, CC (123 m).

3. Sample $397-5-2,9-11 \mathrm{~cm}(39 \mathrm{~m})$.

Figure $4 \quad$ Dictyocha sp. (apical sphere).

Sample 397-7-5, 129-131 cm (64 m).

Figure 5 Distephanus sp. (irregular).

Sample 397-7-5, 129-131 cm (64 m).

Figures 6,7 Dictyocha sp. (pustulate ring).

Sample $397-13$, CC (123 m).

Figure 8 Dictyocha? sp. (irregular).

Sample 397-10-3, 119-121 cm (89 m).

Figures 9-18 Panicoid class.

9,10. Sample 397-13, CC (123 m).

11. Sample 397-16-5, $49-51 \mathrm{~cm}(149 \mathrm{~m})$.

12,15 . Sample $397-21-4,79-81 \mathrm{~cm}(195 \mathrm{~m})$.

$13,16,18$. Sample 397-15-6, 49-51 cm (141 m).

14. Sample 397-11-5, 59-61 cm (101 m).

17. Sample $397-6-4,59-61 \mathrm{~cm}(52 \mathrm{~m})$. 
PLATE 7
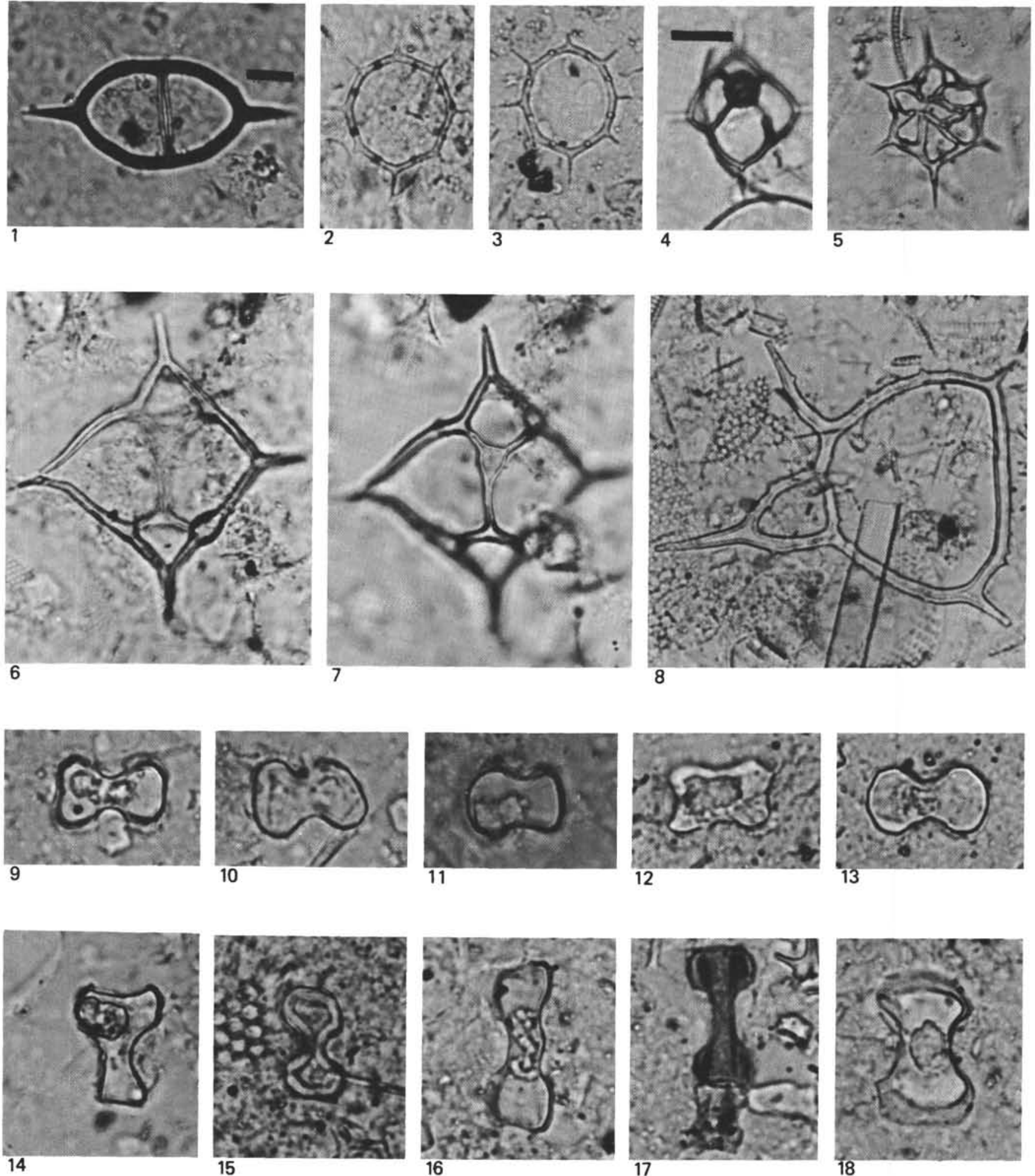


\section{PLATE 8}

Opal Phytoliths From Site 397

Figures 9,10 magnified $2050 \times$; scale bar equals $5 \mu \mathrm{m}$.

Figures 1-6,11,12 magnified $1050 \times$; scale bar equals $10 \mu \mathrm{m}$.

Figures 8,13 magnified $800 \times$; scale bar equals $10 \mu \mathrm{m}$.

Figure 7 magnified $550 \times$; scale bar equals $20 \mu \mathrm{m}$.

Figures 1-6 Panicoid class.

1. Sample 397-11-5, 59-61 cm (101 m).

2. Sample $397-16-5,49-51 \mathrm{~cm}(149 \mathrm{~m})$.

3. Sample $397-6-4,59-61 \mathrm{~cm}(52 \mathrm{~m})$.

4. Sample 397-15-6, 49-51 cm (141 m).

5. Sample $397-3-5,79-81 \mathrm{~cm}(25 \mathrm{~m})$.

6. Sample $397-13$, CC (123 m).

Figures 7-10 Silicified epidermal tissue showing sites of panicoid phytolith formation.

Sample 397-21-4, 79-81 cm (195 m).

Figures 11-13 Elongate class.

11,13. Sample 397-11-5, 59-61 cm (101 m).

12. Sample $397-16-5,49-51 \mathrm{~cm}(149 \mathrm{~m})$. 


\section{PLATE 8}
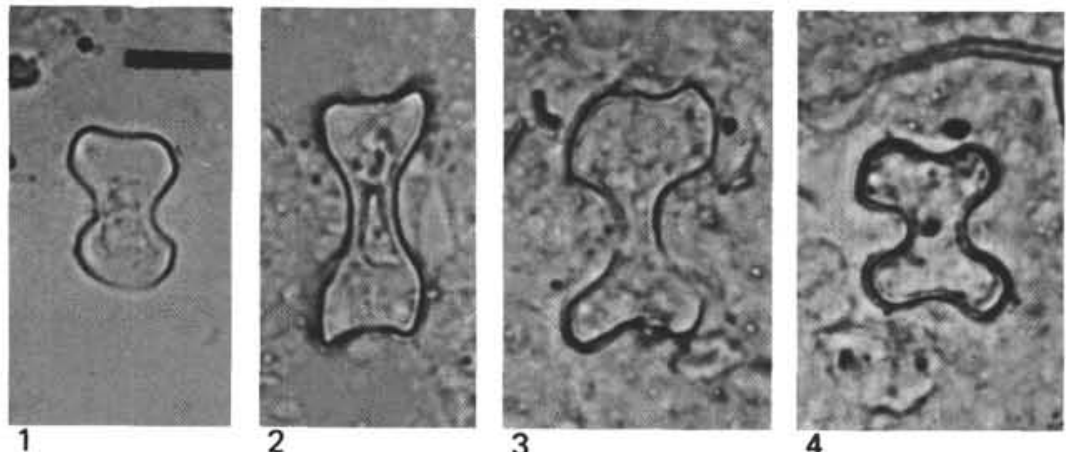
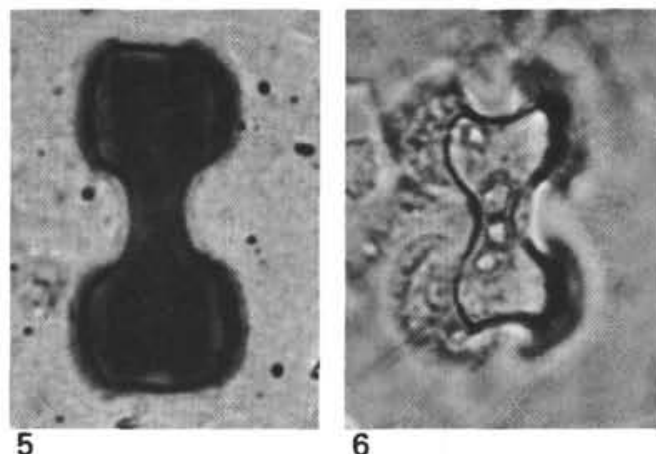
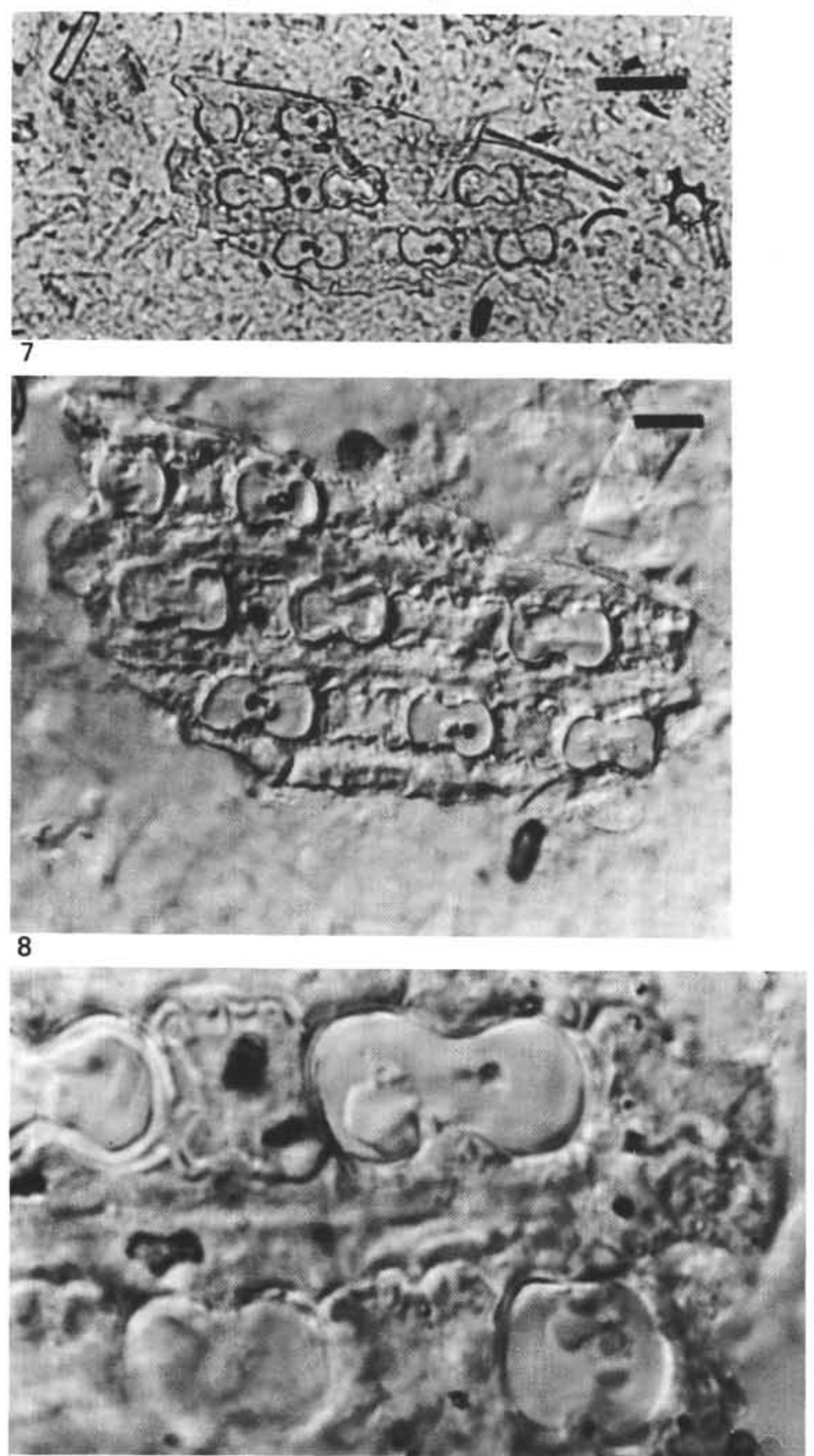

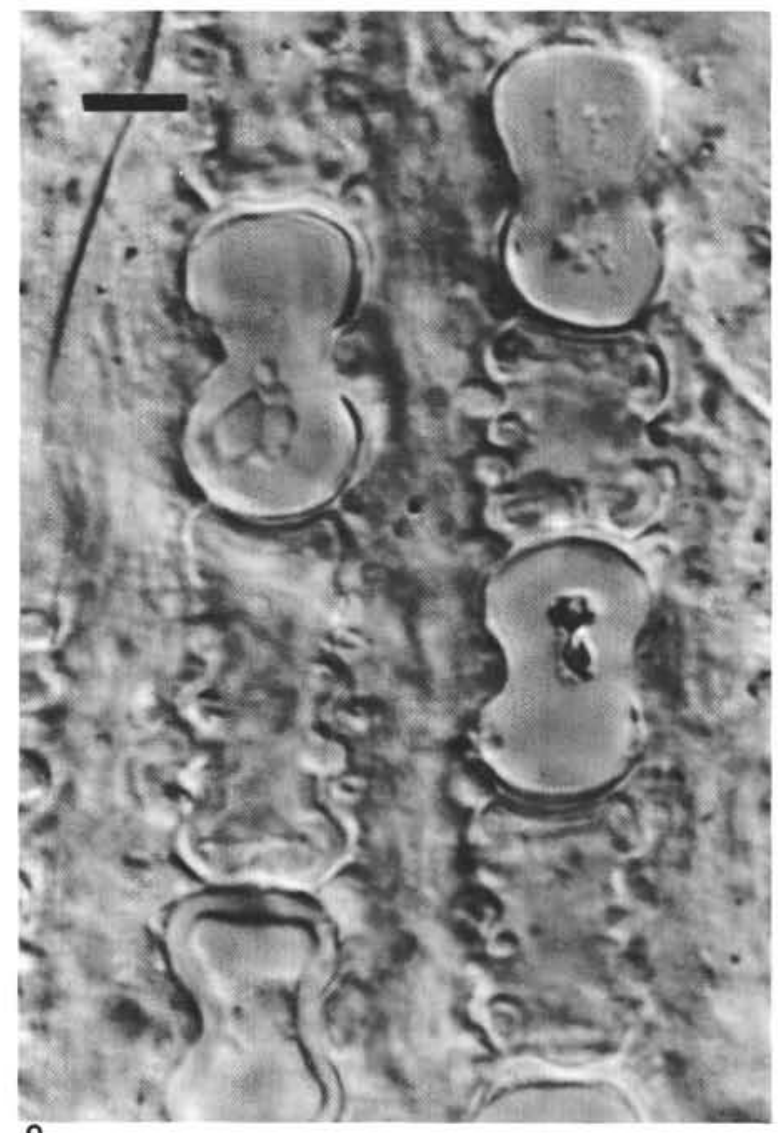

\section{9}

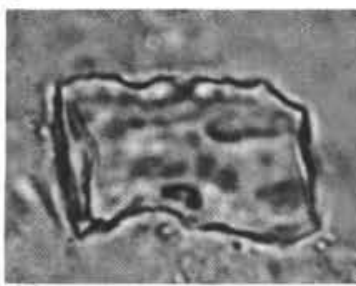

13

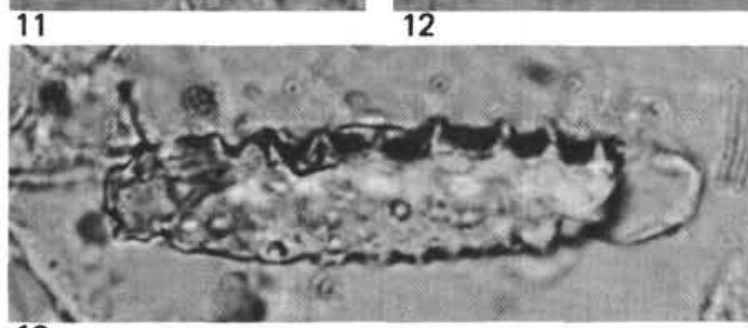

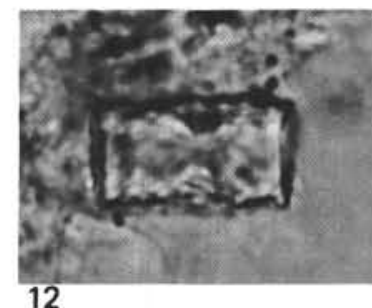


PLATE 9

Opal Phytoliths (Figure 1-10) and Diatoms

(Figures 11-20) From Site 397

Figures 4,5,8-12,17 magnified $1050 \times$; scale bar equals $10 \mu \mathrm{m}$.

Figures $1-3,6,7,13-15,18-20$ magnified $800 \times$; scale bar equals

$10 \mu \mathrm{m}$.

Figure 16 magnified $400 \times$; scale bar equals $20 \mu \mathrm{m}$.

Figures 1-5 Elongate class.

1. Sample $397-21-4,79-81 \mathrm{~cm}$ (195 m).

2,3. Sample 397-11-5, 59-61 cm (101 m).

4. Sample $397-15-6,49-51 \mathrm{~cm}$ (141 m).

5. Sample $397-6-4,59-61 \mathrm{~cm}(52 \mathrm{~m})$.

Figures 6,7 Elongate-like bodies.

Sample 397-11-5, 59-61 cm (101 m).

Figure $8 \quad$ Festucoid class.

Sample 397-6-4, 59-61 cm (52 m).

Figures 9,10 Festucoid-like bodies similar to those of Sieglingia (Smithson, 1958).

9. Sample 397-15-6, 49-51 cm (141 m).

10. Sample $397-13$, CC (123 m).

Fresh-water Diatoms associated with Opal Phytoliths

Figures 11,12 Melosira granulata Ehrenberg.

11. Sample 397-11-5, 59-61 cm (101 m).

12. Sample $397-16-5,49-51 \mathrm{~cm}$ (149 m).

Figure 13 Stephanodiscus astrea (Ehrenberg).

Sample 397-11-5, 59-61 cm (101 m).

Benthic or Littoral Diatoms

Figures 14,15 Auliscus spp.

14. Sample $397-7-5,129-131 \mathrm{~cm}(64 \mathrm{~m})$.

15. Sample $397-21-4,79-81 \mathrm{~cm}$ (195 m).

Figure $16 \quad$ Biddulphia sp. aff. B. culcitella Mann.

Sample 397-11-5, 59-61 cm (101 m).

Figures 17,18 Cocconeis sp.

17. Sample $397-4-4,51-52 \mathrm{~cm}(33 \mathrm{~m})$.

18. Sample $397-8-4,48-50 \mathrm{~cm}$ (73 m).

Figures 19,20 Epithemia zebra (Ehrenberg).

Sample 397-16-5, 49-51 cm (149 m). High and low focus. 

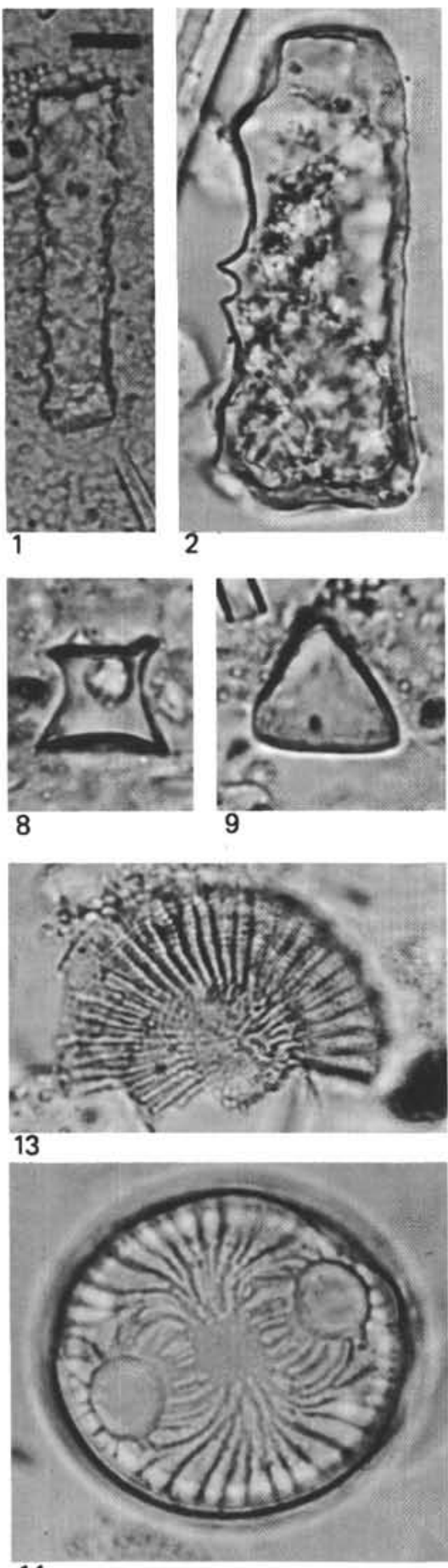

14
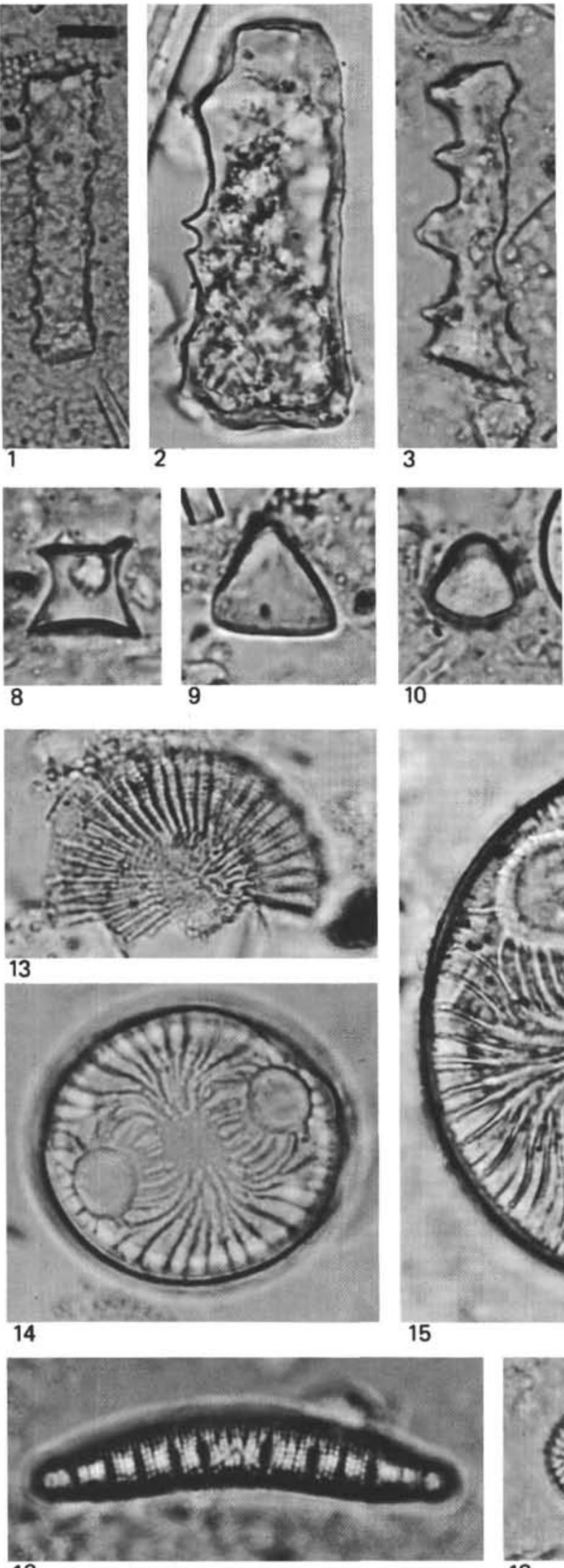

PLATE 9
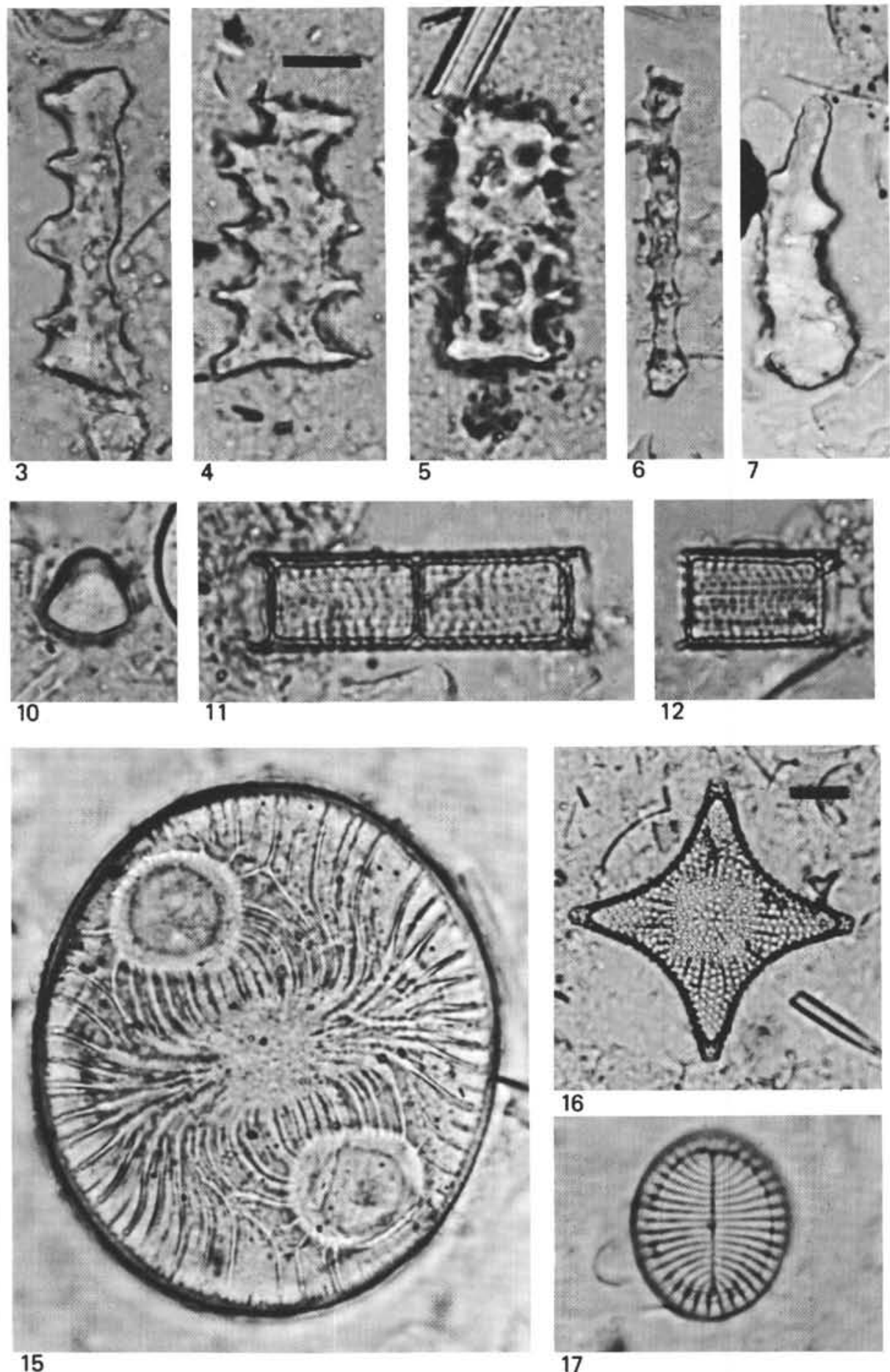

17
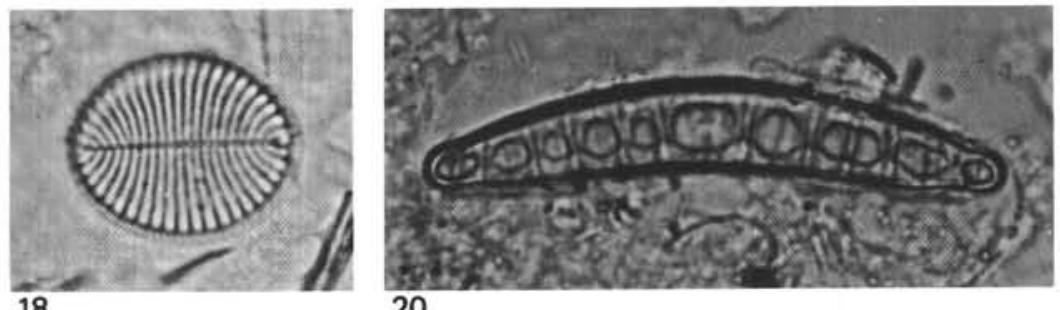

20 


\section{PLATE 10 \\ Diatoms From Site 397}

Figures 1,11,12 magnified $1050 \times$; scale bar equals $10 \mu \mathrm{m}$.

Figures $3,4,6,7,9,10,13,14$ magnified $800 \times$; scale bar equals $10 \mu \mathrm{m}$.

Figure 5 magnified $400 \times$; scale bar equals $20 \mu \mathrm{m}$.

Figures 2,8 magnified $350 \times$; scale bar equals $20 \mu \mathrm{m}$.

\section{Benthic and Littoral Diatoms}

Figure $1 \quad$ Epithemia zebra (Ehrenberg).

Sample 397-21-4, 79-81 cm (195 m).

Figure 2 Grammatophora undulata Ehrenberg.

Sample 397-21-4, 79-81 cm (195 m).

Figure $3 \quad$ Mastogloia rutilans Brun.

Sample 397-3-5, 79-81 cm (25 m).

Figure $4 \quad$ Navicula sp. cf. N. lyra dilatata Schmidt.

Sample 397-4-4, 51-52 cm (33 m).

Figure $5 \quad$ Stictodiscus parallelus hexagona (Castracane).

Sample 397-8-4, 48-50 cm (73 m).

Figures 6,7 Surirella fastuosa Ehrenberg. Sample 397-8-4, 48-50 cm (73 m). High and low focus.

Figure $8 \quad$ Triceratium(?) favus Ehrenberg. Sample 397-21-4, 79-81 cm (195 m).

Other Marine Diatoms From Site 397

Figures 9,10 Annellus californicus Brébisson. Sample 397-15-6, 49-51 cm (141 m). High and low focus.

Figures 11,12 Rhaphoneis sp.

Sample 397-4-4, 51-52 cm (33 m).

Figure $13 \quad$ Rhizosolenia sp.

Sample 397-15-6, 49-51 cm (141 m).

Figure 14 Thalassiosira convexa Mukhina.

Sample 397-21-4,79-81 cm(195 m). 
PLATE 10
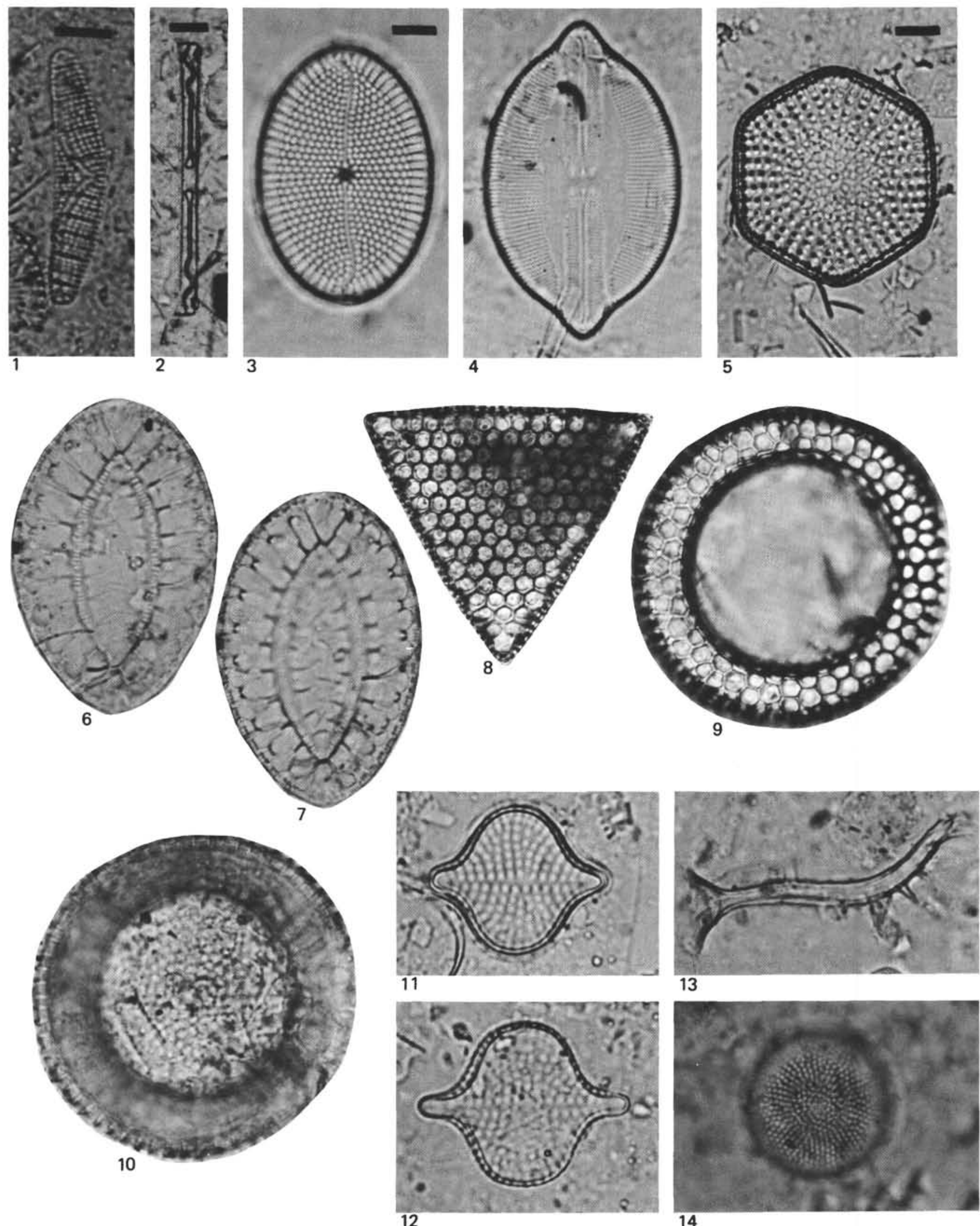